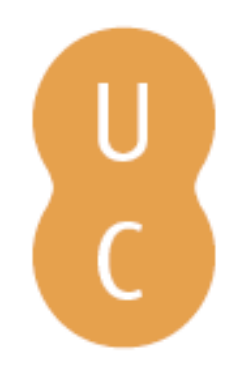

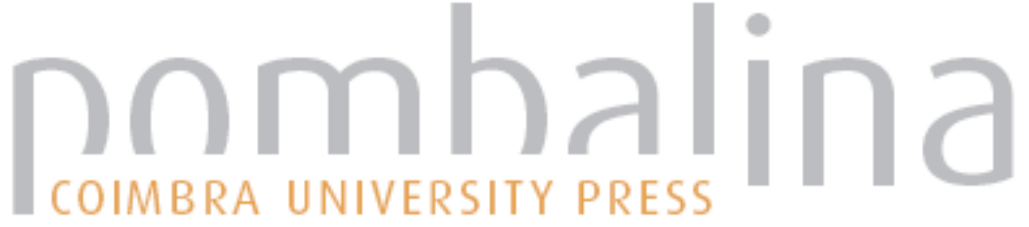

\section{Do oitavo passageiro ao clone número oito}
Autor(es):
Rodrigues, Elsa Margarida
Publicado por: Imprensa da Universidade de Coimbra
URL persistente:
URI:http://hdl.handle.net/10316.2/11953
DOI:
DOI:http://dx.doi.org/10.14195/978-989-26-0312-4

Accessed : $\quad$ 26-Apr-2023 09:42:11

A navegação consulta e descarregamento dos títulos inseridos nas Bibliotecas Digitais UC Digitalis, UC Pombalina e UC Impactum, pressupõem a aceitação plena e sem reservas dos Termos e Condições de Uso destas Bibliotecas Digitais, disponíveis em https://digitalis.uc.pt/pt-pt/termos.

Conforme exposto nos referidos Termos e Condições de Uso, o descarregamento de títulos de acesso restrito requer uma licença válida de autorização devendo o utilizador aceder ao(s) documento(s) a partir de um endereço de IP da instituição detentora da supramencionada licença.

Ao utilizador é apenas permitido o descarregamento para uso pessoal, pelo que o emprego do(s) título(s) descarregado(s) para outro fim, designadamente comercial, carece de autorização do respetivo autor ou editor da obra.

Na medida em que todas as obras da UC Digitalis se encontram protegidas pelo Código do Direito de Autor e Direitos Conexos e demais legislação aplicável, toda a cópia, parcial ou total, deste documento, nos casos em que é legalmente admitida, deverá conter ou fazer-se acompanhar por este aviso.

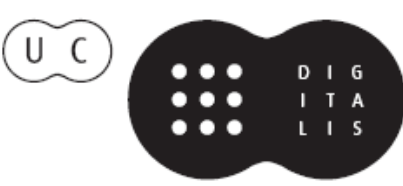




\section{DO OITAVO PASSAGEIRO} AO CLCN! NÚMER $\%$. OITO

ELSA MARGARIDA RODRIGUES

7.

IMPRENSA DA UNIVERSIDADE DE COIMBRA COIMBRA UNIVERSITY PRESS 
(Página deixada propositadamente em branco) 
悬

$\frac{\mathrm{I}}{\mathrm{U}}$ 


\section{EDIÇÃO}

Imprensa da Universidade de Coimbra

Email: imprensauc@ci.uc.pt

URL: http://www.uc.pt/imprensa_uc

Vendas online: http://livrariadaimprensa.com

\section{CONCEPÇÃO GRÁFICA}

António Barros

INFOGRAFIA DA CAPA

Carlos Costa

PRÉ-IMPRESSÃO

Mickael Silva

Imprensa da Universidade de Coimbra

\section{EXECUÇÃO GRÁFICA}

www.artipol.net

ISBN

978-989-26-0141-0

ISBN Digital

978-989-26-0312-4

DOI

http://dx.doi.org/10.14195/978-989-26-0312-4

DEPÓSITO LEGAL

340196/12 
DO OITAVO PASSAGEIRO AO CLONE NÚMERO OITO

ELSA MARGARIDA

RODRIGUES

IMPRENSA DA UNIVERSIDADE DE COIMBRA
COIMBRA UNIVERSITY PRESS 
(Página deixada propositadamente em branco) 


\section{SUMÁRIO}

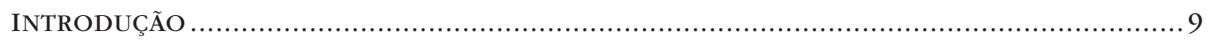

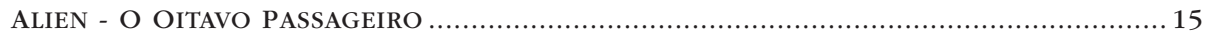

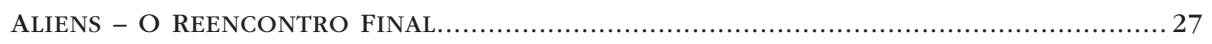

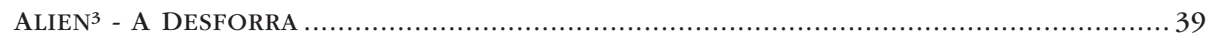

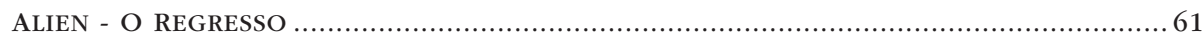

HUMANOS E NÃO HUMANOS NOS FILMES ALIEN ..................................................... 79

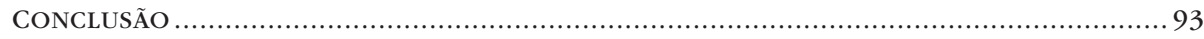

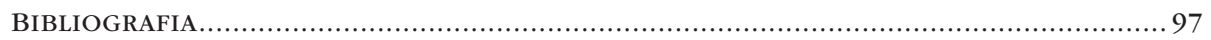

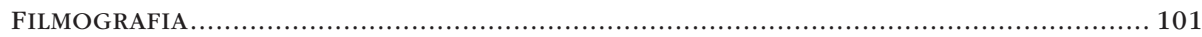


(Página deixada propositadamente em branco) 
There's a monster in your chest.

Ellen Ripley 
(Página deixada propositadamente em branco) 


\section{INTRODUÇÃ O}

Do oitavo passageiro da nave Nostromo a Ripley, clone número oito de Alien - O Regresso, a saga Alien oferece uma imensa galeria de entidades onde humano e não humano se confrontam e fundem, concretizando no ecrã os piores medos em relação à biologia, à tecnologia, à ciência e à economia. A imagem do alien a irromper do peito de Kane, ícone da série e uma das mais perturbadoras da história do cinema, é ilustrativa desta capacidade de inquietar o espetador, de o fazer saltar da cadeira e o confrontar com os seus temores fisiológicos relativos à contaminação, à incubação, à possessão, ao parto, e com angústias em relação ao radicalmente diferente, ao anormal, ao estranho que, afinal, pode estar dentro de cada humano.

A ficção é sempre um reflexo possível da realidade em que é produzida. A ficção científica vai mais longe. É uma projeção do mundo real distendido no tempo e no espaço, desobrigado do realismo mimético mas vinculado às leis físicas e princípios do conhecimento existente. Aborda os problemas e ansiedades do momento histórico, deslocando-as para outro espaço-tempo onde assumem novas configurações, contidas no limite do possível, daquilo que, à luz da realidade presente, poderá efetivamente acontecer.

Ao longo das últimas décadas foram várias as ansiedades que a ficção científica refletiu: a relação com a tecnologia e com a ciência, as reconfigurações a que a Terra estará sujeita com o passar do tempo, o medo daquilo que é diferente, não familiar e a própria reconfiguração do humano, tornado ele próprio cada vez mais em estranho, lugar cruzamento entre o biológico e o maquínico, o natural e o artificial, o real e o virtual. 
Esta espécie de condição alienígena da humanidade em relação a si própria desloca a questão da alteridade para o centro da identidade, tema que atravessa de maneira decisiva a ficção científica recente. É a partir dos binómios eu/outro e humano/não humano e das hibridações que deles resultam, que se forma uma noção imaginada de humanidade, daquilo que constitui a essência do ser humano e que a ficção científica constrói a partir do encontro com entidades alienígenas ou mecânicas, articulando graus de otimismo ou pessimismo em relação à humanidade, à tecnologia e à ciência, concretizados em narrativas utópicas ou distópicas, mas que têm como objetivo permitir a reflexão e construção de um tempo e um espaço melhores.

Os filmes Alien constituem-se como exemplares do cinema das últimas quatro décadas na abordagem da questão das fronteiras entre o humano e o não humano e da relação com a ciência e a tecnologia. Pode mesmo considerar-se que, tematicamente, os filmes refletem a filmografia da ficção científica dos últimos quarenta anos. Apesar de decorrerem apenas dezoito anos entre o lançamento de Alien - O Oitavo Passageiro (1979) e Alien O Regresso (1997), a diversidade de abordagem em cada filme permite traduzir as ansiedades científicas e tecnológicas dominantes em cada momento. Mas há outras razões que fazem da tetralogia um excelente produto de entretenimento e objeto de análise. Antes de mais, os quatro filmes oferecem grande parte das personagens tipo e da iconografia da ficção científica. Além da espécie alienígena nos vários estádios de desenvolvimento, a saga, no seu conjunto, contém uma grande diversidade de naves, planetas, estações espaciais, armas tecnologicamente avançadas, androides, computadores, clones, cientistas, militares, Companhias e personagens ao serviço dos seus interesses, compondo grande parte do universo imagético da ficção científica cinematográfica das últimas décadas.

Além disso, tendo uma origem claramente norte americana, os filmes são ilustrativos da globalização dos produtos culturais, quer ao nível da difusão, quer da própria produção. Apesar de serem propriedade de uma grande companhia americana, a 20th Century Fox, os filmes são o resultado da imaginação de criadores de diferentes nacionalidades. Dos quatro realizadores, apenas David Fincher nasceu nos Estados Unidos. Ridley Scott 
nasceu em Inglaterra, James Cameron é canadiano e Jean-Pierre Jeunet é francês. O design do alien e do planeta LV426 pertence ao suíço H. R. Giger e os filmes foram filmados nos dois continentes, sendo lançados quase simultaneamente no mercado europeu e americano.

A análise da saga permite comprovar ainda outras tendências gerais do cinema. Em primeiro lugar, comprova a fluidez da autoria. Nos quatro filmes, a ideia é atribuída a Dan O’Bannon, mas apenas no primeiro filme ele intervém diretamente na escrita de uma versão embrionária do argumento e na indicação dos designers responsáveis pela conceção do planeta LV426, da espécie alienígena e da nave Nostromo. A introdução da personagem Ripley, essencial para estabelecer a continuidade da série, não se deve a O'Bannon mas à vontade de Ridley Scott, e Ash, o androide, é da responsabilidade de Walter Hill e David Giller. O design do alien no seu estado adulto e do planeta LV426 deve-se a H. R. Giger e a nave Nostromo a Ron Cobb. O filme é, deste modo, um produto cujo resultado depende de múltiplas ideias e vontades, sem que se possa indicar um centro de autoria claramente definido.

Herdeiro de todos estes elementos, o segundo filme foi escrito e realizado por James Cameron, num processo de autoria mais contido, que se volta a diluir e fragmentar no terceiro filme da série. No Alien ${ }^{3}$ - A desforra, a atribuição da criação é não só complexa, como pouco pacífica. Depois do sucesso de Aliens - O Reencontro Final, era natural que a 20th Century Fox continuasse a aposta na série, por isso, nos seis anos que medeiam o segundo e o terceiro filmes foram escritos vários guiões e propostos diversos realizadores. Mas a versão que chega às salas de cinema acaba por ser realizada por David Fincher, que se estreia na realização de longas metragens sem que exista um guião definitivo no início das filmagens.

O quarto filme da série carrega as marcas autorais de Joss Whedon, argumentista das séries televisivas Buffy e Angel, e de Jean-Pierre Jeunet, realizador de Delicatessen (1991), A cidade das crianças perdidas (1995) e O fabuloso destino de Amélie Poulain (2001), que acrescentam à série uma parafernália de novos elementos. O quarto Alien é, eventualmente, o filme que melhor ilustra a afirmação de que os textos cinematográficos não são um mero produto, mas contêm em si os estádios do processo de criação, condicionados 
pelos filmes anteriores e por toda a história do cinema. São textos densos (thick texts), noção que Rick Kaveney (2005) utiliza para sublinhar as múltiplas linhas, físicas e textuais, que cosem os filmes, articulando compromissos entre as visões pessoais, a história do género, o estado de desenvolvimento das técnicas de produção e as exigências do mercado.

Apesar das diferentes visões, propostas pelos diversos autores e equipas de trabalho, há uma continuidade na série garantida pela manutenção de um inimigo, o alien, e de uma personagem, Ellen Ripley, que trava duas lutas: uma contra o monstro biológico para defender a humanidade do não humano, outra contra o monstro moral, a Companhia, para defender a humanidade de si própria. Ripley, alien e Companhia acabam por marcar a identidade da saga. Daí deriva uma outra razão que leva à escolha de Alien: o facto de poder ser analisado como uma afirmação do género feminino. Alien é o filme em que primeiro aparece uma heroína de ação, em que uma mulher combate monstros e vence, sem perder a sua feminilidade, antecipando as heroínas de ação como Lara Croft, que iriam marcar o cinema a partir da década de 1990. Na história da relação de Ellen Ripley com o alien estão também presentes as questões da sexualidade e da maternidade, abertas a múltiplas interpretações de acordo com o ângulo e metáfora escolhida.

Um outro aspeto que torna a série exemplar das tendências reveladas pela ficção científica e pelo cinema em geral é o facto de a ficção científica nunca ter perdido a sua ligação ao magazine, à continuação da história na edição seguinte, como acontecia nas suas origens enquanto pulp fiction. Esta tendência, presente no cinema dos últimos vinte anos, permite fidelizar públicos e rentabilizar fórmulas testadas, gerando sucessos comerciais. Quer o cinema enquanto medium, quer a ficção científica enquanto género literário e cinematográfico, assentam na relação de familiaridade do espetador com os elementos da narrativa. O formato magazine permite o trabalho imaginativo do leitor durante o tempo de espera até ao número seguinte, a antecipação e o acompanhamento da construção da história, como acontece no caso Alien, em todas as sequelas realizadas e no quinto filme que se encontra em produção.

Típica também da ficção científica é a hibridez genológica, a tendência para a agregação ou fusão com outros géneros narrativos. A saga é exemplar 
nessa hibridação, mostrando ligações a géneros como o terror, a ação, o filme de guerra e até a comédia.

Central à saga, à ficção científica em geral e a este livro enquanto proposta de leitura dos quatro filmes Alien, é a questão da identidade e hibridação do próprio sujeito, tema central da cultura pós-moderna. A hibridação humano/máquina e a hibridação humano/monstro, que obrigam a uma reflexão sobre o que é especificamente humano, são claramente abordadas nos quatro filmes. A definição do humano é feita por contraste com a estranheza do alien e das máquinas, oferecendo-se, ao longo das quatro narrativas, múltiplas formas de pensar a alteridade, a tecnologia, o tempo e o espaço, que refletem as ansiedades e medos do momento histórico em que foram realizados.

Finalmente, um outro motivo que pode ser apontado para a importância destes filmes na história do cinema de ficção científica é o facto de eles resumirem a ambiguidade a que o género se encontra preso nas últimas décadas, entre uma visão antropologicamente pessimista e um otimismo redentor que permite a salvação. Consciente de que, independentemente do tempo e espaço em que se encontre, o ser humano é o pior inimigo da sua espécie, a necessidade antropológica de esperança e a necessidade comercial de finais felizes obrigam a que, no fim, as qualidades humanas triunfem sobre os defeitos e consigam resgatar a humanidade - ou aquilo que ela representa - dos outros e de si própria. Mas sem esquecer, como os quatro filmes continuamente avisam, que os monstros continuam a habitar dentro de nós. 
(Página deixada propositadamente em branco) 


\section{Alien - O Oitavo PASSAgeiro}

In space no one can bear you scream.

Ao contrário do que acontece no filme Star Wars, a saga Alien não foi pensada antecipadamente. Não existe continuidade temporal, espacial nem mesmo temática ao longo dos quatro filmes, os argumentistas e realizadores são diferentes e antecipa-se que o quinto filme da série seja uma prequela, uma narrativa do que aconteceu no planeta LV426 antes da chegada da nave Nostromo. Aquilo que permite garantir alguma continuidade em todos os filmes Alien é a companhia cinematográfica responsável pela sua produção, a 20th Century Fox, uma personagem, Ellen Ripley, interpretada por Sigourney Weaver, e uma espécie alienígena que, tal como Ripley, sofre profundas metamorfoses ao longo dos quatro filmes.

A acreditar numa das verdades de Hollywood que a experiência frequentemente valida, cada sequela é mais pobre do que o filme anterior, o que faz de Alien - O Oitavo Passageiro o melhor filme da série, e de Alien O Regresso o pior, embora se possa argumentar que este contém grande parte dos elementos iconográficos do género e que aborda os temas que se encontram nos filmes anteriores da saga e em toda a ficção científica das décadas de 1990 e 2000.

A ideia original da história de Alien é atribuída a Dan O’Bannon, que, em 1970, colaborara com John Carpenter na realização de Dark Star, um filme sobre astronautas numa nave espacial, lançado em 1975.

O argumento apresentado por O'Bannon chamava-se Starbeast e foi levado à 20th Century Fox por Ronald Shusett, que também contribuiu para a redação 
do argumento original. O projeto foi entregue a Gordon Caroll, produtor proprietário da Brandywine, de que Walter Hill e David Giller eram sócios. Giller e Hill foram os responsáveis pela redação que transforma Starbeast em Alien, introduzindo no guião as duas personagens femininas e o androide Ash.

Walter Hill recusou a realização do filme alegando a sua inexperiência no género, e Sandy Lieberson, responsável pela produção europeia da Fox, sugeriu o nome de Ridley Scott como realizador. Scott era inglês e realizara alguns episódios de séries britânicas ${ }^{1}$, antes de se estrear, em 1977, com filme The Duellists, uma adaptação de um conto de Joseph Conrad. Numa homenagem de Ridley Scott a Conrad, a nave de Alien vai chamar-se Nostromo, título do romance publicado em 1904, cuja ação decorre na imaginária cidade mineira de Sulaco. Sete anos depois, num jogo de intertextualidade entre os dois filmes, James Cameron usará Sulaco como nome da nave do filme Aliens - O Reencontro Final.

Antes de começar a realizar o filme, Scott passou algum tempo nos Estados Unidos com Dan O'Bannon e Ronald Shusett, que lhe mostraram o trabalho de H. R. Giger, designer industrial e pintor, que acaba por ser o responsável pela conceção do cenário de LV426 e do ser alienígena no seu estado adulto. O'Bannon foi também creditado como consultor de design visual e propõe o nome de Ron Cobb para desenhar a nave Nostromo.

Embora 2001- Odisseia no Espaço tenha abordado de modo sério a solidão no espaço e a fé na conquista espacial, credibilizando a ficção científica enquanto género cinematográfico, Alien - O Oitavo Passageiro contribui também para isso num registo mais próximo do filme de terror, assumidamente tecnofóbico. A nave tem um ar gasto, usado, a tecnologia nem sempre funciona e a tripulação parece cansada, sentido-se uma tensão latente entre os vários membros. E, pela primeira vez na história da ficção científica, a heroína do filme é uma mulher, Ellen Ripley, representada pela até então relativamente desconhecida Sigourney Weaver $^{2}$.

${ }^{1}$ Enquanto realizador, Ridley Scott participou nas séries The Troubleshooters (um episódio, 1969), The Informer (dois episódios, 1967), Half Hour Story (um episódio, 1967), Adam Adamant Lives! (três episódios, 1966-1967), Thirty-Minute Theatre (um episódio, 1966), Z Cars (um episódio, 1965), Boy and Bicycle (1965).

2 No cinema, Sigourney tinha apenas desempenhado um pequeno papel em Annie Hall e entrado no filme israelita Madman. 
Além de Sigourney Weaver, o filme conta com a participação de Tom Skerrit, Veronica Cartwright, Harry Dean Stanton, John Hurt, Ian Holm, Yaphett Kotto, que desempenham respetivamente os papéis de oficial substituto Ellen Ripley, Capitão Dallas, navegador Lambert, engenheiro técnico Brett, oficial executivo Kane, oficial científico Ash e engenheiro chefe Parker, além de Bolaji Badeno, o estudante nigeriano que vestiu o fato que dá forma ao ser alienígena.

O filme foi lançado com a frase promocional 'No espaço ninguém pode ouvir-te gritar', que comprova a intencionalidade da fusão entre géneros: se a referência ao espaço remete claramente para a ficção científica, o grito é uma alusão aos filmes de terror, que o conteúdo do filme comprova. Bukatman (1993:263) considera esta ligação ao terror um dos aspetos mais negativos do filme, que acaba por transformar um espaço futurista cuidadosamente elaborado num mero contexto para a narração da caçada a um intruso alienígena, o que, para Bukatman, gera um caos estilístico.

Os primeiros minutos do filme reforçam a aproximação ao terror. No ecrã, surge a indicação de que a Nostromo é uma nave comercial que transporta minério, informação que afasta a noção de exploração ou aventura espacial. A imagem de quatro torres escuras a flutuar no espaço remete para o imaginário de casa assombrada. Ao contrário da iconografia típica do género, não é uma nave brilhante de formas perfeitas e tecnologia cromada. É uma imagem que provoca mais apreensão do que encantamento e faz o espetador antecipar que o que se irá passar na nave não será agradável.

O tracking pelo interior da nave, ao longo de corredores escuros e vazios, com tubagem visível, reforça a ideia de abandono e desamparo, de perigo vago, sugerido pelo flutuar das batas penduradas à passagem da câmara. São claramente usados os dispositivos narrativos típicos do filme de terror, mostrando, ao longo de quatro minutos, computadores desliga$\operatorname{dos}^{3}$, folhas a esvoaçar e capacetes vazios como se a Nostromo fosse uma nave fantasma. De acordo com Bukatman (1993:262), a evacuação do humano desta visão detalhada da nave complementa a diminuição da figura

\footnotetext{
$3 \mathrm{Na}$ realidade, para a nave continuar a navegar, ainda que em piloto automático, os computadores não deveriam estar desligados.
} 
humana que ocorre nos cenários de ficção científica, amplificado aqui pela escala monstruosa da Nostromo.

A vida parece regressar à nave quando os computadores se ligam, emitindo sons e linhas de códigos que se projetam alternadamente nos capacetes vazios, como se substituíssem os seus utilizadores. O computador é a força anímica da nave, coordenando o despertar de equipamentos e seres humanos. A câmara de Scott mostra esse acordar acompanhando o acender sucessivo de luzes pelos corredores até ao compartimento onde os tripulantes estão deitados em hipersono. As luzes ganham mais intensidade e as tampas levantam-se das câmaras dispostas em círculo, formando uma espécie de flor. O predomínio do branco remete para uma esterilização e pureza que contrasta com o tom sombrio do resto da nave e com o que acontecerá ao longo do filme.

Kane é a primeira personagem a acordar, filmada numa sucessão de planos fundidos. O facto de ser o primeiro a acordar parece indiciar que terá uma importância decisiva no filme e cria no espetador um investimento emocional que tornará mais dramática a sua morte.

A cena seguinte passa-se na messe e serve para dar a conhecer os sete passageiros: Kane, Dallas, Lambert, Ripley, Parker, Brett e Ash. Está também presente um gato, Jones, o que acentua a ideia de informalidade a bordo e torna o cenário futurista mais próximo da vivência doméstica do espetador.

Apesar da primeira refeição decorrer num ambiente descontraído, há um confronto entre Parker e Dallas que sugere um conflito de classes na estrutura socioprofissional da tripulação. Parker pede mais dinheiro para ele e para Brett e Dallas responde que receberá o que está no contrato. A hierarquia socioprofissional entre Parker e Brett e os restantes tripulantes é reforçada por outros indícios: Parker é negro e Brett tem um aspeto pouco cuidado, acentuado pelo boné, claramente desnecessário numa nave.

Além de dar a conhecer os sete tripulantes e de estabelecer as relações de antagonismo existentes a bordo da nave, esta cena permite à audiência estabelecer uma relação de identificação com as personagens. Ainda nesta cena, um som intermitente e uma luz amarela chamam Dallas ao computador central. É dada a conhecer mais uma personagem, um dos oitavos passageiros da Nostromo. Mother é o nome escolhido para esta entidade tecnológica, 
situada numa divisão circular como um útero, com painéis de luzes intermitentes e sons ritmados como batimentos cardíacos filtrados, que provocam a sensação de organismo vivo, vibrante e quente. No seu interior, como um filho no ventre materno, Dallas é informado sobre o destino da Nostromo.

A cena seguinte permite perceber as funções dos membros da tripulação. Kane e Lambert estão sentados nos comandos da nave, Ripley e Ash estão mais atrás. O problema define-se: a Nostromo, que deveria estar próxima do planeta Terra, está perdida. Ripley contacta com o controlador de tráfego para tentar descobrir a posição. O plano seguinte é uma visão lateral da Nostromo, com as suas torres e sombras, e a voz off de Ripley a tentar contactar o controlador, uma voz perdida na imensidão do espaço. Dallas explica à tripulação que Mother interrompeu o percurso de regresso à Terra porque captou a transmissão de um sinal acústico que pode ser um pedido de ajuda. Parker refere novamente a necessidade de pagamento extra para uma situação de salvamento e Ash responde, mostrando um conhecimento detalhado do regulamento, com a cláusula que obriga a que qualquer transmissão recebida com origem em vida inteligente seja investigada, sob a pena de perda total do bónus. Um novo plano da nave mostra uma perspetiva em que aparecem várias cúpulas invertidas, em forma de seios, de diferentes tamanhos. A estratégia de Ridley Scott parece ser a de dar ao espetador um conjunto fragmentado de imagens da nave, obrigando-o a imaginar uma configuração final.

Um módulo liberta-se das torres e navega em direção ao planeta com todos os tripulantes a bordo. Ao contrário do que tradicionalmente acontece nos filmes de ficção científica, a viagem e o processo de aterragem não são rápidos nem suaves. A viagem faz-se com turbulência e a aterragem é violenta, obrigando a reparações.

A nave está imobilizada e continua a receber o sinal de doze em doze segundos. Lambert fuma sozinha, com o rosto apreensivo. Quando é filmado um plano de conjunto, Lambert aparece focada, enquanto os homens ficam em segundo plano, desfocados. Até este momento do filme não há qualquer indicação clara de quem irá assumir o protagonismo, parecendo mais provável que Kane, Lambert ou Dallas desempenhem o papel principal no decurso dos acontecimentos. 
É organizada uma expedição ao planeta. No exterior, ouve-se o barulho do vento, marcando a hostilidade dos elementos. Dallas, Lambert e Kane saem. O conforto de Ash, que fica na nave, e o silêncio do interior contrastam fortemente com os planos do exterior em que se ouve a violência do vento.

No planeta LV426 é descoberta uma nave alienígena, frequentemente interpretada como uma metáfora ao sistema reprodutor feminino. A sua forma é semelhante às trompas de Falópio, as três entradas parecem vaginas e o interior é um túnel estriado e escuro, brilhante como se estivesse húmido. A única iluminação é a dos capacetes dos tripulantes. Já no interior, Kane descobre e indica aos companheiros algo de diferente, que o espetador não vê. Há um plano de Kane a trepar lentamente, antecipando o monstro tal como aparecerá mais tarde: luvas brilhantes e húmidas como garras, exterior do capacete escuro e brilhante, movimentos lentos. Descobrem o esqueleto fossilizado de um alien, uma espécie sobre a qual não será fornecida qualquer informação e que ficará conhecida como space jockey. A iluminação continua a ser ténue e o tom dominante é o escuro, impedindo uma visão clara e detalhada.

A imagem passa para Ripley. A ligação entre os planos é significativa. Há um grande plano do rosto fossilizado do alien sentado numa cadeira enquanto Lambert pergunta o que terá acontecido aos outros seres daquela espécie, seguido de um grande plano do rosto de Ripley, também ela sentada, antecipando que possa vir a ter o mesmo destino do space jockey: ser a última sobrevivente de uma nave.

Entretanto Ripley diz a Ash que a mensagem parece mais um aviso do que um pedido de socorro e Ash impede-a de sair para alertar os companheiros. Na nave alienígena, Kane desce para uma caverna e cai no meio de ovos, cobertos por uma névoa azulada. Há um grande plano de um dos ovos, translúcido, mostrando vida orgânica no seu interior. Repentinamente este abre-se e sai dele um pequeno ser que se cola ao capacete de Kane. Este é o momento pelo qual o espetador esperou mais de meia hora de filme. A partir daí sabe que a tripulação da Nostromo está em perigo.

A cena seguinte é de Dallas e Lambert a transportarem Kane para a nave. Ripley recusa-se a abrir a porta da nave, evocando o regime obrigatório de 
quarentena. É Ash quem abre a escotilha, perante a insistência dos outros e a recusa de Ripley, que é dada como uma personagem pouco inspiradora de simpatia. O objetivo confessado de Ridley Scott era criar uma tripulação em que todos tivessem, aos olhos do espetador, as mesmas hipóteses de sobreviver e de se transformarem no herói da narrativa.

Ash e Dallas tentam remover o parasita que envolve a face de Kane, conhecido na história da ficção científica como face hugger. Ao ser tocado, o face hugger aperta a garganta de Kane com a cauda, tornando impossível a sua remoção sem perigo para Kane. Apesar disso, Dallas insiste em tirar o parasita da cara de Kane, assumindo a responsabilidade perante Ash, que tenta demovê-lo. Ash experimenta cortar um dos dedos do face hugger, mas do corte sai um ácido que abre de imediato um buraco no chão. Perante a ameaça de corrosão do casco, Dallas, Ripley, Brett e Parker seguem o percurso do ácido até ao segundo convés, onde começa a parar.

Na cena seguinte, a câmara assume o ponto de vista de Ripley para despertar no espetador desconfiança em relação a Ash, que observa algo num ecrã e num microscópio. Ripley pergunta o que é que ele está a observar. Ash responde que ainda não sabe e desliga o ecrã. Ripley confronta-o com o facto de ter deixado entrar os tripulantes, quebrando a lei básica da quarentena, lembrando-o de que, quando Dallas e Kane não estão, ela é o oficial mais graduado da nave. Ash acaba a conversa dizendo-lhe para ela fazer o trabalho dela e deixá-lo fazer o dele, um trabalho (científico) que se assume não ser transparente nem desinteressado.

Entretanto o face hugger liberta-se. O rosto de Kane aparece, marcado pelos sulcos dos dedos do alien. Ripley e Dallas entram com cuidado no laboratório para procurar o ser. É um momento de suspense, em que as três personagens se movem lentamente e com cuidado. A queda de um móvel cria um falso clímax e o alien acaba por cair inesperadamente em cima de Ripley.

A tensão é aliviada com a descoberta de que o ser está morto. Ash, Ripley e Dallas observam o corpo do alien (que é na realidade um composto de matéria plástica recheado de entranhas de peixe e ostras). Ash quer levá-lo para ser estudado na Terra, Ripley não concorda e Dallas acaba por delegar a decisão em Ash. Ripley e Dallas discutem sobre Ash. Dallas conta que Ash substituiu o oficial de investigação dois dias antes do início 
da missão, criando suspeitas sobre as intenções da Companhia. O vaivém regressa à Nostromo. A tripulação reúne-se novamente na messe. É o momento mais descontraído de todo o filme. Os tripulantes dizem piadas e, numa das cenas mais memoráveis da ficção científica, o alien a irrompe do peito de Kane. Enquanto chestburster o alien configura os piores medos: é um parasita que rasga as entranhas do hospedeiro, matando-o. A imagem é tão inesperada, rápida e violenta que causa um impacto profundo. Em contraponto, o funeral de Kane é emocionalmente neutro. Nada é dito pelos restantes passageiros enquanto o corpo, envolvido num lençol branco, é disparado para o espaço, revelando a falta de ligação afetiva do grupo.

A caça ao alien é feita com armas rudimentares: incineradores e aguilhões que dão descargas elétricas. Não é explicado se existem outras armas a bordo e se decidem não as utilizar por causa do ácido que os animais soltam ou se efetivamente não há capacidade de defesa e ataque. Ash mostra ao grupo um leitor de movimentos que deteta variações na densidade do ar, o instrumento tecnologicamente mais avançado na preparação da caçada.

Fatos espaciais vazios pendem do teto, como condenados numa forca. O gato Jones foge e Brett vai procurá-lo sozinho. Chega a uma divisão húmida, onde cai água do teto e existem correntes a abanar como se houvesse vento, um cenário mais adequado a filmes de terror. O efeito sonoro das correntes, conjugado com o som de batimentos cardíacos de diferentes intensidades, acentua a sensação de perigo. Brett encontra Jones num canto. O plano contém também a imagem do alien. Segue-se uma montagem rápida de um grande plano do alien, um grande plano de Brett, um grande plano dos dentes do alien e um grande plano da cara do gato a rosnar, deixando subentender a morte de Brett.

Dallas consulta Mother sobre a nova situação e esta mostra-se incapaz de responder alegando insuficiência de dados. Decidem então tentar encurralar e matar o alien nas condutas de ar, por onde pensam que ele se desloca. Os efeitos sonoros que acompanham a cena de Dallas nas condutas são batimentos cardíacos, o bip do leitor de movimento e o som da respiração de Dallas. Dallas e o alien são pontos que se aproximam pontos no leitor de movimentos, num crescendo de sons e de ansiedade, até se sobreporem. 
Ripley assume o comando e descobre, na Mother, a diretiva 937, destinada ao oficial de ciência, onde lê que a prioridade máxima é a recolha do organismo para análise, sendo a tripulação prescindível ${ }^{4}$.

O plano do ecrã da Mother é substituído por um plano do perfil de Ripley, com Ash silenciosamente a seu lado. Este diz-lhe que há uma explicação para o que acabou de ler. Ripley afasta-o e sai. Corre sangue do nariz de Ripley enquanto em Ash uma substância esverdeada sai de um golpe, num contraste cromático que sublinha a diferença orgânica entre ambos.

Apesar de estar latente em todo o filme, a desconfiança em relação a Ash traduz a desconfiança em relação à ciência e em relação à tecnologia também. Ash é um produto tecnológico que incorpora uma frieza e amoralismo que Ridley Scott associou à prática científica. A sua malevolência concretiza-se no ataque a Ripley. Arranca-lhe cabelos e atira-a para uma das cabines. As imagens seguintes têm uma conotação sexual forte. A cabine tem posters eróticos na parede e Ash tenta asfixiar Ripley com uma revista pornográfica. É salva por Parker, que bate em Ash com um extintor, arrancando-lhe a cabeça e mostrando, para lá de qualquer dúvida, a sua constituição mecânica.

Ripley sugere que a Companhia quereria a espécie alienígena para a divisão de armamento. Ash é ligado. A voz é agora claramente artificial. Ripley pergunta-lhe como podem matar o alien e Ash responde que não podem, manifestando o seu respeito pelo organismo. Considera que a sua perfeição estrutural só é comparável à hostilidade: o inimigo perfeito, sem consciência, remorso ou ilusões morais. A admiração de Ash revela a conceção de humano à luz da máquina: um ser impuro, contaminado pelas emoções e pela moralidade. Enquanto produto tecnológico programado para fazer ciência, o discurso de Ash sobre o alien corresponde ao discurso científico-tecnológico da modernidade. Ripley desliga Ash e Parker, num gesto de raiva que comprova os excessos humanos, queima-o.

O grupo decide arriscar fazer a viagem para Terra no vaivém, mesmo com excesso de carga. Na agitação das preparações ouve-se um miado.

\footnotetext{
${ }^{4}$ No original: Nostromo reorientado para novas coordenadas. Investigar forma de vida. Recolher espécime. Prioridade um: garantir o regresso do organismo para análise. Todas as outras considerações secundárias. Tripulação dispensável.
} 
Ripley procura Jones e Parker e Lambert carregam líquido de refrigeração. A banda sonora é novamente o bater ritmado de um coração, indiciando o perigo que se aproxima. Jones serve novamente de engodo. Salta repentinamente, assustando Ripley. O plano seguinte indica onde está o verdadeiro perigo: Lambert volta-se para passar uma unidade de refrigeração a Parker e depara com o alien. Esta cena é alternada com planos de Ripley no vaivém. O ataque é mediado, desta vez pelo intercomunicador: o que o espetador não vê pode construir imaginativamente a partir dos sons que Ripley ouve. Parker tenta salvar Lambert e é atacado pelo alien. Lambert paralisa e não consegue fugir.

Há mais uma vez uma sugestão sexual muito forte: a cauda fálica do alien sobe pela perna e coxa de Lambert, que nesta imagem está vestida e calçada. Quando Ripley chega ao local, apenas se vê o corpo de Parker sentado e as pernas pendentes de Lambert, nuas e ensanguentadas.

Ripley, a sobrevivente final (a final girl dos filmes de terror), aciona o sistema de autodestruição da nave e prepara-se para fugir com Jones. Tenta invalidar o mecanismo de autodestruição e não consegue. Grita para o computador: "Mãe, voltei a ligar a unidade de refrigeração! Mãe..."

Os efeitos sonoros são agora bastante intensos: sirenes, barulho e o aviso informático do tempo que falta para a autodestruição da nave. As luzes são avermelhadas e intermitentes. Abandonada pela Mother, Ripley volta ao vaivém para tentar sobreviver. Neste momento, há dois mecanismos de tensão: o alien e a autodestruição da nave.

$\mathrm{Na}$ versão do realizador há uma cena entre a tentativa de parar a autodestruição da nave a entrada no vaivém, em que Ripley desce para um nível inferior da Nostromo e encontra Brett e Dallas, dos quais nunca foram mostrados os corpos, transformados em casulos. Dallas está vivo e pede para ser morto e Ripley usa a unidade incineradora para os matar.

Uma vez no vaivém, é a partir do ponto de vista de Ripley que vemos a Nostromo enquanto se afasta. Depois da explosão da nave, Ripley descontrai e o espetador relaxa também. Abraça Jones e coloca-o na câmara de sono. Começa a despir-se. Não há banda sonora, como se toda a agitação anterior tivesse dado lugar ao silêncio e à paz. Já despida, começa a programar o vaivém para regressar a casa e o filme parece resolvido. 
Mas Scott tem ainda uma surpresa. Sem explicar como, o alien também entrara no vaivém. Está camuflado na tubagem e move-se. Ripley percebe-o e recua. Veste o fato espacial. Vê o alien mover-se muito lentamente, sem abandonar a posição junto às tubagens. Ripley aproxima-se, senta-se na cadeira, aperta o cinto. Canta nervosamente You are my lucky star. Provoca uma descarga de vapor que faz afastar o alien. Vira-se de costas. Olha pelo capacete. Tem o monstro atrás de si. Carrega no botão que abre as portas do vaivém. O alien fica preso à porta. Ela dispara um arpão e fecha a porta, lançando-o para o espaço. A imagem seguinte é a de Ripley vestida com um roupão branco e Jones ao colo, a fazer o relatório final. O plano que encerra o filme é dela, deitada na câmara de vidro como uma bela adormecida. Este plano dissolve-se num plano do espaço estrelado onde desfila o genérico final.

O filme pode considerar-se uma distopia tecnofóbica. Distopia, porque retrata um tempo pior do que o presente, um futuro implicitamente regulado pelos interesses económicos e por uma racionalidade científico-tecnológica amoral, que se sobrepõem ao respeito pela vida humana.

Apesar de Alien - O Oitavo Passageiro abrir a série e ser responsável pela conceção e criação do monstro, não é centrado na alteridade mas no modo como a tecnologia poderá impor-se à vontade individual, ameaçando os valores e integridade humanas e estabelecendo-se como fator que permite construir um espaço hostil e postular um futuro menos feliz do que o presente, revelando medos e ansiedades em relação aos avanços da ciência, da tecnologia e do capitalismo.

As entidades mecânicas, o androide Ash e o computador Mother, são forças negativas que fazem perigar a tripulação devido à ausência de emoções. No entanto, sendo Ash um oficial médico, a fobia tecnológica estende-se à prática científica, mostrada como dependente de interesses comerciais, políticos ou militares e desligada de preocupações éticas ou morais.

Embora retrate negativamente a alteridade enquanto agente de destruição, o filme não redime o humano. Ridley Scott revela pouco otimismo antropológico, sublinhando os conflitos de classe e a ausência de laços afetivos entre os membros da tripulação. 
O tom dominante do filme é o de pessimismo, quer em relação à capacidade de os humanos se organizarem para resistir às ameaças externas, quer em relação à possibilidade de construírem um futuro que evite os perigos do presente. Não poderá sequer classificar-se este filme como uma distopia crítica porque, além de não explicar o modo como se chegou ao estado distópico, não propõe estratégias de resistência ou luta para além do engenho individual de uma heroína que, no final, estabelece um paralelismo icónico com a Bela Adormecida dos contos infantis. 


\section{ALIENS - O REENCONTRO FINAL}

This time it's war!

Nos anos que mediaram o lançamento de Alien - O Oitavo Passageiro e o aparecimento de uma sequela, Ridley Scott realizou Blade Runner - Perigo Iminente (1982) e James Cameron realizou O Exterminador Implacável (1984), dois filmes que marcaram de forma decisiva o cinema de ficção científica.

Uma sequela de Alien estava no horizonte da 20th Century Fox. A bilheteira do primeiro filme chegou aos quarenta e oito milhões de dólares e obteve o reconhecimento da Academia com a atribuição de um Óscar para efeitos visuais, em 1980. A produtora Brandywine viu em Cameron um digno sucessor de Ridley Scott. Pela primeira e única vez na história de Alien, uma única pessoa acumulou as tarefas de argumentista e realizador, e, embora Aliens - O Reencontro Final seja construído tendo como pano de fundo a história e os dispositivos narrativos do primeiro filme, pode atribuir-se a Cameron a autoria do filme.

Como refere Roz Kaveney (2005:154), o primeiro filme é mais simples e austero. Os diálogos do filme de Ridley Scott são utilitários e as personagens menos estereotipadas. Cameron é mais maniqueísta, sublinhando a oposição entre o heroísmo e a vilania, apostando na capacidade de redenção. Sendo também um filme de transgressão de fronteiras entre a ficção científica e o terror, Aliens acrescenta o tom militar, presente nas cenas de combate e estratégia, na hierarquização das personagens e nos diálogos. A frase promocional "Desta vez é guerra!" antecipa o aumento do ritmo de ação. Já não se trata da história de uma tripulação assustada e sem 
capacidade de defesa perante um organismo aparentemente invulnerável, mas de um segundo confronto, em que espetador e personagens estão mais preparados para o que os espera. Como refere Martin Flanagan ${ }^{5}$, os filmes da série Alien refletem as tendências cinematográficas de cada década. Deste modo, enquanto Alien - O Oitavo Passageiro capitaliza o boom de filmes de terror dos anos 1970, Aliens - O Reencontro Final surge num contexto em que filmes como Rambo (Cosmatos, 1985) e Commando (Lester, 1985) faziam sucesso nas bilheteiras.

Apesar das diferenças narrativas, há uma clara continuidade temática e estrutural entre os dois filmes. O elenco repete Sigourney Weaver no papel de Ellen Ripley, e apresenta Carrie Henn como Rebecca 'Newt' Jorden, Michael Biehn como Dwayne Hicks, Lance Henriksen como Bishop, Paul Reiser no papel de Carter Burke, Bill Paxton como Hudson, William Hope no papel de Gorman, Jenette Goldstein como Vasquez, Al Matthews como Sargento Apone, Mark Rolston como Drake, Ricco Ross como Frost, Colette Hiller como Ferro, Daniel Kash como Spunkmeyer, Cynthia Dale Scott como Dietrich, e Tip Tipping como Crowe. A nave Sulaco foi desenhada por Rob Cobb, o homem que concebeu a Nostromo. No entanto, os efeitos visuais, apesar de atribuídos novamente a H. R. Giger, foram da responsabilidade de Stan Winston, que participara na equipa de O Exterminador Implacável.

Ao contrário de Ridley Scott, que tentou que o espetador não pudesse adivinhar a ordem pela qual os tripulantes da Nostromo morriam, distribuindo de modo relativamente equitativo o protagonismo dos atores, no filme de Cameron é fácil adivinhar quais as personagens que têm hipótese de sobreviver mais tempo, numa estratégia mais típica de Hollywood, apostando também em diálogos rápidos, precisos, económicos e bem interpretados, que contribuem para a fluidez do filme e para o seu sucesso comercial.

O genérico inicial é construído com linhas paralelas, uma espécie de gradeamento que se afasta e forma a palavra aliens. A letra i eclode em luz e dá lugar ao negro do espaço. De uma nebulosa azul, destaca-se um pequeno ponto branco. O ponto aproxima-se, percebendo-se que é um vaivém. A cena

\footnotetext{
5 The Alien Series and Generic Hybridity, in Cartmell et al., 1999:156-171.
} 
seguinte passa-se no seu interior. Os viajantes estão em hipersono e o rosto de Ripley é visível, estabelecendo a ponte com o primeiro filme. A imagem seguinte é da atracagem a uma nave maior, antecipando que a tranquilidade do sono está prestes a ser substituída pela ação de um novo filme.

Do espaço, é feita uma panorâmica que permite identificar a Terra à distância, em fusão com o rosto de Ripley, a que se seguem imagens de uma estação espacial.

Estabelecida a geografia da ação, passa-se, sem perda de tempo, para o cenário branco e assético de um hospital. Uma enfermeira anuncia a Ripley que tem uma visita e entra um homem de fato cinzento, Burke, que leva consigo o gato Jones, personagem do filme anterior. O homem diz que pertence à Companhia, mas garante que, apesar disso, é boa pessoa. É através de Burke que o espetador fica a saber que Ripley esteve cinquenta e sete anos à deriva no espaço.

Depois desta revelação, acontece o primeiro momento de tensão. Jones começa a rosnar, mostrando que alguma coisa não está bem. Ripley agita-se, grita e o gato foge. É mostrado um grande plano dos dentes de Jones, como acontecera na morte de Brett. Burke chama ajuda. Ripley pede para a matarem, levanta a bata e vê-se um movimento que parte do interior da barriga, como se um alien fosse irromper. Mas este dispositivo é um engodo. Ripley acorda na sua cama de hospital e verifica o estômago. A enfermeira pergunta se é um pesadelo, revelando que se trata de um sonho recorrente, e oferece-lhe algo para dormir, que ela recusa alegando que já dormiu o suficiente.Na versão do realizador, segue-se uma cena em que Ripley, sentada num jardim pacífico (que na realidade é uma projeção holográfica) é visitada novamente por Burke que a informa da morte Annie, a filha que Ripley deixara na Terra ao partir na Nostromo. Esta cena, apagada na versão que chegou às salas de cinema, fundamenta a ligação de Ripley a Newt, a criança com a qual irá estabelecer uma relação maternal.

Ripley é levada a uma comissão que investiga a destruição da Nostromo. Todos os presentes, à exceção de Ripley, vestem fato, marca da institucionalização, da Companhia. Num ecrã, passam letras em verde e fotos dos tripulantes da Nostromo, elemento de ligação ao primeiro filme que permite 
conhecer ou rever as anteriores personagens e lembrar ou saber a sua sorte. A única mulher presente na reunião questiona a credibilidade de Ripley por esta relatar acontecimentos nunca antes registados em trezentos mundos conhecidos. Este é um dado que permite perceber o avanço da Terra em termos de viagem e colonização espacial. Sabe-se também que LV426 é agora um planeta colonizado, em fase de terraformação, onde habitam cerca de setenta famílias. No computador, letras verdes escrevem o estatuto do caso: encerrado.

Com a economia narrativa característica de todo o filme, Cameron define o problema: Ripley é informada por Burke e um militar, Gorman, que se perdeu o contacto com LV426. Os homens pedem-lhe que os acompanhe como consultora numa expedição ao planeta, para o caso de encontrarem a espécie alienígena. No decurso do diálogo fica a saber-se que Ripley trabalha com empilhadores, informação que se mostrará útil no decurso do filme. Ripley recusa integrar a expedição, mas um novo pesadelo faz com que mude de ideias e integre a tripulação da Sulaco. Ao contrário da Nostromo, a nave é mostrada em poucos segundos e tem um ar bélico, reforçado pela forma fálica. A partir desse momento começa o filme de guerra. Logo que a tripulação da Sulaco acorda do hipersono reconhecem-se as convenções narrativas do filme de guerra, que se juntam à grelha de ficção científica subjacente. Os tripulantes aproximam-se dos estereótipos militares que o cinema cultivou: o sargento duro mas altruísta, o superior sem capacidade ou experiência, o herói discreto, o cobarde fala-barato. Cameron, num tratamento ambivalente da feminilidade, acrescenta as personagens Vasquez, militar latina e masculinizada, a jovem sobrevivente Newt e a própria Ripley, personagens que se revelam mais capazes e sensatas do que os homens.

Os compartimentos de sono da Sulaco não estão dispostos em círculo mas em linha, com Ripley a ocupar a posição inicial. Como em Alien - O Oitavo Passageiro, a cena que se segue ao acordar decorre na messe. Estabelece-se também uma hierarquia: Burke, Gorman e Ripley, a quem se junta Bishop, fazem a sua refeição numa mesa separada dos outros tripulantes. O ambiente é de camaradagem entre os militares, que pedem a Bishop para fazer o truque da faca: passar rapidamente a lâmina por entre os dedos da 
sua mão, sobreposta à mão de Hudson. A cena estabelece simultaneamente a cobardia de Hudson e a natureza não humana de Bishop, revelada pelo líquido branco que corre de um pequeno golpe no dedo.

Ripley reage violentamente por não ter sido informada da existência de um androide a bordo e Bishop responde que prefere a expressão 'pessoa artificial', numa alusão aos conceitos politicamente corretos da década de 1980. Explica, numa referência intertextual às três leis da robótica de Asimov, que ele é de um modelo que não poderá fazer mal aos humanos.

Passa-se de seguida ao briefing, que o Tenente Gorman explica não ter havido tempo para fazer antes. Falam sobre o tipo de combate que será. Empregando também uma designação politicamente correta, Gorman usa a palavra xenomorfos para se referir aos aliens, enquanto os soldados se referem a eles como bugs. Vasquez interrompe a descrição de Ripley sobre o que acontecera na Nostromo para afirmar que só precisa de saber uma coisa: onde é que eles estão. Acrescenta um gesto de disparo, que faz os camaradas rir. Vasquez é alvo de piadas sobre aliens ilegais, numa alusão às políticas de imigração norte-americanas que se esperaria estarem resolvidas num futuro tão distante.

Começam as preparações para a descida até ao planeta. Ripley oferece-se para ajudar. Perguntam o que sabe fazer e ela responde que sabe usar o empilhador. Apone e Hicks ficam impressionados com a sua destreza e Cameron estabelece mais uma competência de Ripley.

Pode considerar-se este filme mais sexista do que o anterior. Apesar da força das heroínas, a surpresa dos homens perante a capacidade de Ripley usar o empilhador e as piadas à masculinidade de Vasquez são misóginas, e as outras duas mulheres, a piloto Ferro e a médica Dietrich, têm uma importância quase insignificante para o desenrolar do filme.

A tripulação assume lugares de combate. Um plano do tanque mostra uma mistura de design moderno e robustez. A eficiência da equipa tem como contraponto a inexperiência de Gorman, que chega a um posto de comando tendo apenas feito simulações de voo e combate.

Tal como Scott, também Cameron usa o som dos elementos para marcar a hostilidade do planeta e acentuar o desconforto do espetador. A aproximação às instalações de LV426 é feita usando táticas militares, comandadas 
por Gorman a partir do tanque, onde fica com Ripley, Bishop e Burke, os quatro personagens da mesa dos oficiais da messe. Nas instalações são detetadas marcas de disparos de armas de pequeno porte.

Tal como no filme anterior, são usados detetores de movimento, cujo som marca o ritmo do suspense. Cameron alterna imagens diretas com imagens captadas pelas câmaras dos capacetes, com a identificação do marine e a hora, que são as que Ripley, Burke e Gorman veem.

Ripley pede a Hicks para fazer um grande plano de um buraco provocado pelo ácido. O espetador sabe que alguma coisa correu mal, mas Cameron prolonga o suspense. Ignorando os avisos de Ripley, Gorman declara a área segura.

Encontram amostras do alien no laboratório médico, suspensas em contentores transparentes. Burke aproxima-se do contentor e o alien move-se, num falso clímax. Bishop lê os relatórios que informam que os aliens foram cirurgicamente removidos dos portadores e que dois ainda estão vivos. Um dos detetores de movimento dá sinal, criando um novo momento de suspense que antecede a descoberta de Newt, a jovem sobrevivente de LV426. Na versão do realizador, lançada em 2003, Newt é dada a conhecer mais cedo, como elemento de uma família de colonos que chega ao planeta.

A relação que se estabelece entre Ripley e Newt é de mãe e filha, mas também de duas sobreviventes. Ripley diz que os soldados estão ali para a proteger, mas Newt responde que não fará qualquer diferença, confirmando o pessimismo que Ripley já revelara.

Bishop, no laboratório, analisa o alien. Diz a Ripley não precisar de qualquer ajuda e, para o espetador do primeiro filme, é deixada no ar a suspeita de que as suas intenções poderão ser semelhantes às de Ash.

A verdadeira ação começa quando os marines descobrem que os colonos estão vivos e reunidos na estação de processamento. Gorman, Burke e Ripley supervisionam à distância o movimento das tropas para os resgatar. Ripley lembra que não podem usar armas por estarem próximos dos tubos do sistema de refrigeração do reator e Gorman comunica aos soldados a proibição do uso de armas sem explicar o motivo. Entregam os magazines a Apone, mas carregam as armas com os suplentes. Depois disso, a velocidade do filme aumenta, marcada por planos cada vez mais 
curtos. Os militares encontram os colonos suspensos e incubados, com os peitos abertos. À sua volta estão ovos vazios. Vasquez levanta a cabeça de uma mulher e ela abre os olhos, pedindo para a matarem. Morre quando um alien irrompe do seu peito. Os soldados assistem ao nascimento da criatura, e incineram-na, juntamente com os corpos dos colonos. Aliens no estado adulto surgem da escuridão, por entre as reentrâncias das paredes, como o alien do primeiro filme saíra da tubagem do vaivém da Nostromo.

Gorman mostra-se incapaz de atuar. As imagens que o espetador vê são as que são captadas pelos capacetes, vagas e difusas mas que dão uma noção de caos. Em poucos segundos morrem dois soldados, Dietrich e Frost, e Apone é apanhado. Ripley tenta que Gorman faça alguma coisa, mas este é incapaz de reagir. Ripley assume o volante do tanque e resgata os soldados. A montagem staccato, a escuridão e a alternância de imagens diretas e indiretas, mediadas pelas câmaras dos capacetes, contribuem para o sucesso das cenas de luta.

Os soldados sobreviventes entram no tanque. Burke, até aí oculto, aparece, como os aliens que saíram da parede, para lembrar que a estação é valiosa e, por isso, não deve ser destruída. Argumenta ainda que não têm o direito de exterminar uma espécie desconhecida. Como porta-voz da Companhia, não autoriza a destruição do planeta, mas Ripley lembra que a operação é militar, por isso a decisão não é dele mas de Hicks, a pessoa que se segue na linha de comando depois de Gorman e Apone.

Cameron assume que, numa situação de conflito entre interesses capitalistas e humanistas, os militares saberiam defender os valores moralmente superiores. Décadas depois assumirá a posição contrária no filme Avatar (2009) colocando interesses capitalistas e militares lado a lado.

Nas cenas seguintes Hicks assume o comando da operação, mas o vaivém que os levaria de volta à Sulaco é atacado por um alien e despenha-se. Perante este revés, Hudson mostra mais uma vez a sua cobardia, enquanto Newt, revelando uma sensatez superior à idade, mantém a calma e avisa Ripley que os aliens atacam sobretudo à noite.

De volta ao interior das instalações Ripley assume a organização da defesa humana. Pede as plantas da estação, fornecendo ao espetador uma visão de conjunto que lhe permite situar a ação. Hicks assume uma postura 
paternal com Newt e, sem que se estabeleça um enredo romântico explícito, é criada uma relação familiar entre Hicks, Ripley e Newt.

Na sequência desta rede relacional, Ripley adormece Newt, que diz uma das frases mais citadas do filme: "A minha mãe disse que não havia monstros a sério, mas há...”.

Ripley coloca em Newt uma pulseira localizadora que Hicks lhe dera e promete não a deixar, promessa que faz mais sentido na versão do realizador, em que se sabe que Ripley prometera à filha Anne que regressaria a tempo de celebrar o seu décimo segundo aniversário. A cena seguinte decorre no laboratório, com Bishop. Ripley pede a Bishop para destruir os aliens conservados no laboratório e ele responde que Burke dera ordem para os guardar.

Ripley confronta Burke, que explica que os aliens valem milhões para a divisão de armamento e sugere fazê-los passar pela quarentena na chegada a Terra, dividindo os lucros com ela. Como resposta, Ripley ameaça denunciar que foi ele que deu ordem para continuar a enviar colonos para LV426 quando já havia razões para suspeitar que o planeta poderia constituir um perigo, e expor o seu plano para levar aliens para Terra. Para aumentar a apreensão, Bishop comunica que a estação irá explodir dentro de quatro horas, explicando que a única salvação é aceder à antena da estação para controlar remotamente o outro vaivém que está na Sulaco para os levar de volta à nave. Bishop oferece-se para o fazer, mostrando que a opção de Cameron perante a tecnologia é contrária à de Ridley Scott.

Hicks ensina Ripley uma usar uma arma antes desta ir verificar Newt, que dorme no laboratório debaixo de uma cama. Deita-se junto a ela e acalma-a do que parece ser um pesadelo. Ripley acorda e vê que o recipiente que continha um dos alien está vazio. Acorda Newt e espreita para cima da cama. O alien salta, provocando no espetador mais um momento de tensão. Ripley e Newt tentam abrir as portas para fugir e descobrem que estão fechadas. Ripley tenta chamar a atenção de Hicks através das câmaras, mas Burke desliga o monitor, revelando que é o responsável pelo que está a acontecer. Ripley faz disparar o alarme de incêndio e os militares correm para as salvar, mas é atacada antes que consigam chegar ao laboratório. Newt grita enquanto outro alien avança sobre ela e é gerado mais 
um clímax. Hudson salva Newt e mata o face hugger que a atacava, enquanto Hicks e Vasquez conseguem retirar aquele que prendia a garganta de Ripley, matando-o também.

Ripley acusa Burke e expõe o seu plano de levar para o planeta Terra os alienígenas nos corpos infetados de Ripley e Newt. Afirma-se novamente que o pior inimigo é o "homem da Companhia", o único capaz de matar por uma percentagem de lucro. Quando Hudson se prepara para matar Burke, a luz é cortada, ficando o grupo iluminado por luzes de emergência. O corte é sinal da inteligência estratégica dos aliens, facto sublinhado por Hudson que até aí os considerara meros animais irracionais. Simultaneamente, os sensores de movimento disparam e há uma construção do suspense marcada pela contagem decrescente dos metros. Os militares recuam e selam as portas atrás de si, mas os detetores continuam a marcar o avanço dos aliens, que estão nas condutas por cima deles. Uma montagem rápida, imagens difusas e uma iluminação feita de luzes de emergência e flashes de disparos são novamente os dispositivos usados por Cameron para acentuar a sensação de confusão e acelerar a pulsação do espetador. Vê-se Hudson ser apanhado por um alien, enquanto Burke se afasta trancando as portas atrás de si, mostrando mais uma vez falta de solidariedade para com os outros humanos. No entanto, ao abrir uma das portas é confrontado com um alien e o seu destino é deixado à imaginação do espetador. Como não podem passar nas portas trancadas por Burke, Newt conduz o grupo pelas condutas em direção à torre onde está a nave que entretanto Bishop conseguira trazer da Sulaco. Os monstros seguem-os. Vasquez dispara sobre um dos aliens, que solta ácido sobre ela, deixando-a incapaz de continuar a fuga. Gorman, o Tenente inexperiente, hesitante e próximo dos interesses da Companhia, redime-se tentando salvá-la, acabando ambos encurralados. Suicidam-se com uma granada, num ato de camaradagem que reabilita a imagem de Gorman.

O impacto da granada empurra Newt, que cai pela conduta quando tenta trepar por um ventilador. Ripley e Hicks correm para salvá-la. Enquanto cortam a grade que os separa dela, o detetor de movimento começa a piscar. O espetador é o único a ver o alien que emerge da água atrás de Newt. Quando Ripley desce, apenas encontra a cabeça da boneca a boiar. 
Na fuga, Hicks é atingido com ácido quando dispara sobre um alien. Ripley leva-o até à nave, pilotada por Bishop, e regressa à estação para salvar Newt. Tal como Scott, Cameron usa a contagem decrescente para a autodestruição como dispositivo de tensão. Ripley desce para o interior da estação e encontra o detetor de Newt caído no chão. Por um momento pensa que a criança já não pode ser salva, mas Newt, que está presa, vê sair um face hugger de dentro do ovo e grita. Ripley corre para a salvar. Descobre que estão entre centenas de ovos e é fornecida a primeira imagem da rainha. Ripley e a rainha, duas mães, encontram-se face a face. Podem destruir-se mutuamente ou podem afastar-se e salvar as suas crias. Ripley afasta-se e, com um sinal da rainha, os guerreiros deixam-na passar sem a atacar. Mas Ripley acaba por quebrar o seu compromisso e, a uma distância segura, dispara o lança-chamas sobre os ovos e sobre os aliens adultos. Este ataque é desnecessário do ponto de vista lógico, uma vez que Ripley sabe que a estação está condenada e não poderá haver salvação para aqueles ovos. Nessa altura, a rainha emite um som equivalente a um grito e rasga o tubo ovipositor que a prendia fisicamente. Assume, como Ripley, a posição de guerreira.

Ripley e Newt usam o elevador para ascender até à plataforma, que está vazia. Por momentos o espetador é levado a pensar que Bishop as abandonara. Ripley abraça Newt e diz-lhe para tapar os olhos. Estão sozinhas na plataforma, entre explosões, com a rainha a aproximar-se. Mas, no último momento, o vaivém surge por detrás delas, salvando-as.

A chegada à Sulaco corresponde ao momento em que Ripley se despe no vaivém da Nostromo. O confronto com o alien já ocorreu, os sobreviventes estão definidos, e prepara-se a viagem final de regresso ao planeta Terra. Ripley congratula Bishop pela maneira como se portou e, nesse momento, uma cauda irrompe pelo peito do androide.

Sublinhe-se que, para acreditar neste desenrolar dos acontecimentos o espetador deveria suspender não apenas a descrença, mas toda a capacidade de raciocínio lógico: a rainha teria de ter apanhado boleia no exterior do vaivém durante os breves segundos em que este sobrevoou a plataforma, ter sobrevivido ao impacto da explosão das instalações e à alta velocidade da nave pelo espaço. 
Na Sulaco, Newt foge para uma conduta no chão da nave e Ripley desaparece. Quando a rainha está quase a apanhar Newt, Ripley surge no monta-cargas, dizendo-lhe para se afastar da criança. São duas fêmeas, dois seres híbridos em que o orgânico e mecânico se fundem, sensação acentuada pelo ar metálico da rainha.

Ao longo da luta caem juntas num compartimento de saída e Ripley abre as portas. Bishop e Newt começam ser sugados para o exterior e Bishop salva Newt, agarrando-a pelo braço enquanto utiliza o outro para se prender. Ripley despe o seu corpo mecânico e consegue salvar-se também, fechando as escotilhas enquanto a rainha flutua no espaço, tal como flutuara o alien do primeiro filme. Newt abraça Ripley e chama-a mamã, confirmando a vinculação maternal, e o espetador sabe que o filme chegou ao fim.

Como no filme anterior, a cena final passa-se no compartimento de hipersono. Newt pergunta a Ripley se pode sonhar. Ripley responde que sim, que ambas podem. A vitória garantiu-lhes o direito de sonhar sem medo.

O filme acaba com o rosto de Ripley e o de Newt em primeiro plano, ambas adormecidas, em direção à Terra.

À semelhança de Alien - O Oitavo Passageiro, a visão proposta por Aliens O Reencontro Final é distópica, mas, ao contrário do que acontecia no filme anterior, o papel da tecnologia é positivo, podendo por isso considerar-se que se trata de uma narrativa que encara o desenvolvimento tecnológico com otimismo.

Por outro lado, o segundo filme centra-se menos na tecnologia e mais no próprio alien, estabelecendo os seus estádios evolutivos, a sua organização social e até a sua capacidade de comunicação com o humano. Os espaços de ação diversificam-se e o futuro, embora discrónico, contém esperança antropológica.

Os interesses económicos continuam a dominar o mundo, usando como aliado o poder militar, que assume uma posição ambivalente mas se mantém fiel aos interesses humanos. A sugestão feita por Burke de recolher o alien para a divisão de armas biológicas e a referência dos soldados a bugs indiciam um estado de guerra entre a Terra e outros planetas. Por outro 
lado, a referência à imigração ilegal sugere que a discriminação continuará a existir num futuro a trezentos anos de distância. No entanto, à imagem de outros filmes da década de oitenta, a posição em relação à tecnologia muda. A visão proposta já não é tecnofóbica, mas tecnofílica. A Sulaco já não é um ambiente assustador e potencialmente perigoso, os vaivéns já não se avariam, não existe computador central e é o androide que salva os sobreviventes.

O não humano continua a ser retratado negativamente, como inimigo, embora a introdução de uma rainha dê aos aliens uma estrutura social que os torna mais inteligíveis. O pessimismo antropológico do primeiro filme dá lugar a um tom mais otimista, que sublinha as relações de camaradagem e a família como estruturas de enquadramento individual e o sacrifício pelo outro como fator de redenção pessoal. 


\section{ALIEN3 - A DESFORRA}

The bitch is back!

O filme Aliens - O Reencontro Final recebeu boas críticas e ultrapassou os quarenta e dois milhões de dólares em receitas no mercado norte-americano. Ripley assume o protagonismo desde o início do filme e consolida a sua imagem como heroína de ação. A academia brindou o filme com sete nomeações para Óscar: melhor atriz principal para Sigourney Waever, melhor direção artística para Peter Lamont e Crispian Sallis, melhor edição para Ray Lovejoy, melhor banda sonora original para James Horner, melhor som para Graham V. Hartstone, Nicolas Le Messurier, Michael A. Carter e Roy Charman, melhor edição de efeitos sonoros para Don Sharpe, e melhores efeitos visuais para Robert Skotak, Stan Winston, John Richardson e Suzanne Benson. A estatueta foi atribuída pelos efeitos visuais e pelos efeitos sonoros, mas a nomeação de Sigourney Weaver para melhor atriz é, em si mesma, uma vitória para a ficção científica e para o género feminino porque, pela primeira vez na história do cinema, uma mulher é nomeada pela sua prestação num filme de ação, ficção científica ou terror.

Depois deste sucesso, a ideia de fazer um terceiro filme da saga parecia natural. As primeiras previsões apontavam para o seu lançamento em 1990. Giller, que entretanto lera o livro Neuromancer, de William Gibson, propõe a Walter Hill contactar o escritor para argumentista do terceiro filme da saga. Gibson, que considerava Alien - O Oitavo Passageiro uma das inspirações para a sua obra, aceita a tarefa. No argumento de Gibson, Newt voltava à terra para viver com os avós e Hicks continuava a ter um papel 
de apoio a Ripley no combate contra a espécie. Giller e Hill acham o argumento muito artístico e pedem a Gibson para o rever em colaboração com o realizador escolhido, Renny Harlin, de origem finlandesa, que realizara Pesadelo em Elm Street 4 (1988) e Die Hard - Assalto ao Aeroporto (1990), outro filme de ação com grande sucesso comercial. Gibson e Harlin não se entenderam quanto ao argumento e Gibson acabou por desistir. Eric Red, que escrevera os argumentos de Depois do Anoitecer (1987) e Terror na Autoestrada (1986), foi contratado em seu lugar. Por esta altura tornara-se incerta a participação de Sigourney Weaver no filme e Red criou um argumento com uma nova personagem principal, um comando dos serviços secretos, e um novo tipo de alien polimórfico. O resultado também não foi consensual e a Brandywine avançou para a contratação de um terceiro argumentista, David Twohy, que escrevera o argumento de Critters 2 (1988) e Warlock (1989). É dele a ideia de um planeta que servisse de prisão.

A participação, ainda que passageira, de todos estes autores faz com que em 1989 o filme tenha já custos elevados sem que exista consenso sobre o tipo de filme a realizar. É então que Giller e Hill contratam o neo-zelandês Vincent Ward, realizador do filme O Navegador (1988), em que uma criança da Idade Média cava um túnel para fugir da Peste Negra e emerge em 1988. Vincent Ward escolhe John Fasano para o ajudar a escrever o argumento. A ação decorreria num pequeno planeta, Arceon, onde uma colónia de monges viveria de um modo medieval. Ripley chegaria ao planeta contando histórias do monstro que provocariam agitação entre os monges. Na luta contra o alien seria ajudada pelo Irmão John e por um androide. Vincent Ward aproveita a ideia do polimorfismo da criatura presente no argumento de Twohy e reintroduz H. R. Giger no projeto. No final, todas as personagens morriam, fechando a saga.

No entanto, alegando incompatibilidades pessoais, Walter Hill despede Vincent Ward e coloca David Fincher no seu lugar, com instruções para simplificar o guião que Ward e Fasano haviam criado ${ }^{6}$. Fincher, na altura

\footnotetext{
6 Kaveney (2005:181) considera que, apesar de toda a indefinição quanto à autoria deste filme, esta poderá atribuir-se a David Fincher, uma vez que Alien³, como Seven (1995), The Game (1997), Fight Club (1999) e The Panic Room (2002), é sobre a presunção dos desejos e aspirações humanas e a demonstração de que os protagonistas não controlam o seu próprio destino.
} 
com vinte e sete anos e sem experiência na realização de filmes, trabalha no argumento com Larry Ferguson. O resultado não foi considerado satisfatório por Giller e Hill, que acabam eles próprios por escrever uma nova versão, em que o mosteiro é convertido novamente em prisão e as várias ideias anteriores são misturadas, numa combinação nem sempre consistente e pouco eficaz do ponto de vista narrativo.

No entanto, o filme é inovador em relação aos anteriores. Uma das diferenças, apontada por Flanagan ${ }^{7}$, é o afastamento em relação a um género cinematográfico reconhecido o que, apesar de o tornar conceptualmente mais denso do que o filme anterior, é também a razão do seu fracasso.

Weaver assina o contrato de participação como atriz e produtora em dezembro de 1990, e sugere algumas ideias que são acrescentadas ao guião. As filmagens começam em janeiro de 1991, sem que o argumento esteja terminado. Os trailers aparecem na primavera de 1991, mas o filme só é lançado no ano seguinte, com um atraso considerável e custos que ultrapassam os cinquenta milhões de dólares.

Do elenco, constam Sigourney Weaver como Ellen Ripley, Charles S. Dutton como Dillon, Charles Dance no papel de Clemens, Paul McGann como Golic, Brian Glove como superintendente Andrews, Ralph Brown como Aaron, Danny Webb como Morse, Christopher John Fields no papel de Rains, Holt McCallany como Júnior, Lance Henriksen como Bishop II, Christopher Fairbank como Murphy, Carl Chase como Frank, Leon Herbert como Boggs, Vincenzo Nicoli como Jude, Pete Postlethwaite como David, Paul Brennen como Troy, Clive Mantle como William, Peter Guinness como Gregor, Deobia Opare como Arthur, Philip Davis como Kevin, Niall Buggy como Eric, Hi Ching como homem da Companhia e Danielle Edmond nas breves imagens de Newt.

O genérico do filme tem como fundo a escuridão estrelada, numa montagem que alterna a vastidão do espaço e planos curtos que resumem o

\footnotetext{
7 The Alien Series and Generic Hybridity, in Cartmell et al., 1999: 156-171. Nas palavras de Flanagan: "O filme aspira a algo mais do que refazer de forma inspirada dos géneros estabelecidos que constituem os primeiro dois filmes, mas falha precisamente devido ao enquadramento genológico do filme. Alien 3 é muito mais rico conceptualmente do que o segundo episódio: regressa à paranóia psicossexual do primeiro filme e, como aponta Amy Taubin, introduz uma nova metáfora que equaciona o alien com o vírus SIDA.”
} 
que aconteceu na Sulaco entre a imagem de Ripley e Newt adormecidas que encerra o filme anterior e o início de Alien $^{3}$ - A desforra.

Logo nos primeiros minutos, o espetador assiste a uma sucessão de imagens do rosto de Ripley no compartimento de hipersono, da Sulaco a viajar no espaço, de um ovo alienígena aberto, suspenso no interior da nave, de um face hugger a abrir os seus 'dedos', do rosto de Newt, do vidro de um dos compartimentos de sono a rachar, de um pingo de ácido a corroer uma superfície branca, de fumo a chegar ao sistema de deteção e de uma imagem radiografada de um rosto envolvido por um face hugger. A voz feminina do computador avisa que a tripulação se deve dirigir à plataforma de lançamento do salva-vidas, e surge a imagem de sangue vermelho a manchar um tecido branco enquanto a voz avisa que o voo para o espaço profundo ocorrerá daí a vinte segundos. Os créditos passam enquanto o espetador vê a imagem de alarmes a dispararem, um êmbolo de seringa a descer, o rosto agitado de Ripley, uma imagem radiográfica de meio corpo, a explosão do que parece ser o sistema de abertura de uma porta e novamente o rosto agitado de Ripley enquanto dorme, em simultâneo com o som de alguma coisa a quebrar. Depois há chamas, um compartimento que fecha e um módulo separa-se da nave e voa em direção a um planeta. No ecrã, surge a designação do planeta: Fiorina 'Fury' 161, refinaria de minério e prisão de segurança máxima para condenados com duplo cromossoma Y.

A ação destes quatro minutos iniciais, que constituem a sequência do genérico, só pode ser plenamente entendida pelos espetadores do segundo filme. No entanto, são usados para afirmar que a experiência a que vão assistir será completamente diferente da anterior. Ripley, a heroína de Cameron, foi, afinal, incapaz de salvar Newt, Hicks e Bishop e de impedir a sobrevivência da espécie alienígena. Este corte abrupto com a história anterior é um dos principais aspetos que fez de Alien $^{3}$ uma desilusão para muitos espetadores que esperavam uma continuidade narrativa, iconográfica e genológica com os filmes anteriores. Kaveney (2005:183) aponta algumas inconsistências a esta sequência inicial: o alien consegue matar Hicks e Newt de formas complicadas e impregnar Ripley com uma rainha sem deixar nela marcas óbvias, mas deixa uma marca de ácido na câmara de Newt e faz tudo isto numa fase larvar, uma vez que não é mostrado qualquer outro vestígio de 
alien adulto a bordo da Sulaco. Por outro lado, a inteligência manifestada na capacidade de destruir os tripulantes adormecidos da Sulaco contrasta com a bestialidade que irá revelar ao longo do filme.

Como repara Flanagan (id.), o complexo Fiorina 161 parece uma instituição mental vitoriana e não uma colónia espacial futura, representando tantos cenários apocalípticos que acaba por não ter identidade própria nem evocar sentimentos claros no espetador, como a claustrofobia despertada pela Nostromo ou a desolação da colónia de LV426.

Sendo resultado da conjugação de elementos de múltiplas visões, o filme revela falta de integridade narrativa, acabando por perder consistência. Giller e Hill optam por transformar o planeta numa prisão de alta segurança, mas aproveitam o tom religioso e medieval do argumento de Vicent Ward. Os diálogos assumem mais importância neste filme do que em qualquer dos filmes anteriores, embora se possa questionar a sua eficácia e potencial reflexivo. Pela primeira vez, Ripley é a única personagem feminina e, pela primeira vez também, a diferença de género está diretamente implicada na relação social e na vivência da sexualidade. É ainda a primeira vez que não há final feliz. O terceiro filme mata heroína e vilão e, com isso, espera encerrar a saga.

Depois do módulo da Sulaco se despenhar no planeta, letras azuis aparecem num ecrã reportando a colisão. Esta comunicação indicia que haverá uma mesma entidade supervisora dos acontecimentos que ocorrem em Fury 161 e a bordo da Sulaco.

Na versão do realizador, lançada na edição especial da saga, em 2003, são fornecidos mais detalhes do planeta, mostrando melhor o modo de vida dos habitantes de Fiorina. A versão que chega às salas de cinema não detalha o contexto. A hostilidade do planeta é marcada apenas pelo barulho do vento e pelo aviso aos homens para se apressarem, evitando os quarenta graus negativos que estarão daí a cinco minutos. As roupas e o aspeto dos homens permitem antecipar que não se trata de um tempo ou de um espaço de tecnologia brilhante.

O interior do módulo da Sulaco é escuro e ensanguentado, com peças e fios soltos. Um primeiro momento de suspense ocorre quando tubos caem 
do teto ao lado de um dos membros da equipa de salvamento. O cão ladra agitado. Para o espetador de Alien - O Oitavo Passageiro, que ainda se lembra de Jones, a agitação do animal assinala a proximidade da espécie alienígena e o perigo que isso representa. No módulo vê-se uma mão rígida e ensanguentada, que se supõe de Hicks. Um dos homens repara que há um corpo vivo e vê-se Ripley, que se move, ainda adormecida, no interior do seu compartimento de hipersono.

Um monitor informático pouco moderno dá os detalhes de Ripley: posto, nome, número, imagem e situação: sobrevivente. A imagem do monitor funde-se na do corpo de Ripley a ser colocada numa maca. O monitor passa a informação relativa a Newt: fêmea não identificada, aproximadamente doze anos, falecida. Segue-se uma imagem de Newt no seu compartimento de sono, com uma mão levantada e a boca aberta num grito. A informação de Hicks aparece em sobreposição à imagem do seu corpo contorcido e ensanguentado, sem que se consiga perceber um rosto. Bishop 341-B, humanoide sintético, classificado com capacidade negativa, é mostrado envolvido num plástico que esvoaça ao vento de Fury 161. As imagens da tripulação morta são alternadas com imagens do corpo de Ripley a ser medicamente tratada.

Os destroços do vaivém são transportados por uma grua, numa breve imagem de Fury 161, e o cão ladra para o interior do módulo da Sulaco enquanto um face bugger se movimenta lentamente nos destroços. Numa primeira alusão à tonalidade religiosa do filme, alguns restos de metal compõem uma cruz que se recorta contra um céu onde dois sóis se põem, deixando o planeta na escuridão.

A cena seguinte passa-se no interior das instalações. A estrutura é em forma de anel, fazendo lembrar o panótico de Jeremy Bentham. Um homem relata aos restantes os acontecimentos recentes, num momento comunicativo designado 'controlo de boatos'. A revelação de que o sobrevivente do salva-vidas é uma mulher provoca agitação. Um dos prisioneiros assume-se como porta-voz da agitação geral, mostrando o pendor religioso da comunidade ali estabelecida. É comunicado aos prisioneiros que a equipa de resgate vem a caminho e chegará dentro de uma semana, e um dos homens que diz que é melhor que se apressem ou não sobrará muito para salvar, mostrando o baixo valor da vida de Ripley naquele planeta. 
Passa-se à enfermaria. Os instrumentos médicos são rudimentares, remetendo para o imaginário médico do século XIX. Um homem prepara uma seringa e Ripley acorda, segurando-lhe a mão antes que ele a possa injetar. O homem apresenta-se como Clemens, chefe médico de Fury 161, uma das prisões pertencentes à Companhia Weyland-Yutani.

Ripley deixa-se injetar. A sua aparência não é boa: tem hematomas em redor do olho esquerdo, um corte na sobrancelha e o próprio olho está raiado de sangue. Clemens conta que ela se despenhou num salva-vidas e aconselha-a a cortar todo o cabelo para evitar os piolhos que há na colónia.

Quando Ripley pergunta o que aconteceu aos outros, Clemens diz-lhe que estão mortos e a mulher levanta-se para ir à nave. Ameaça ir nua se Clemens não lhe arranjar roupas. A carga sexual do filme é relativamente explícita nesta cena. Enquanto procura roupas para que Ripley se vista, Clemens tenta explicar-lhe o perigo que corre, já que os prisioneiros há vários anos que não veem uma mulher, acrescentando que ele próprio também não. No percurso em direção à nave, Clemens conta que Fury 161 albergava cinco mil condenados, reduzidos agora a uma população de vinte e cinco homens que mantêm acesa a luz piloto de uma fundição onde se faziam folhas de chumbo para contentores de resíduos tóxicos.

Uma vez chegados aos destroços do salva-vidas, Clemens explica que Hicks fora empalado pela armação de segurança, Bishop fora desligado e colocado no depósito do lixo e que Newt morrera afogada no tubo criogénico. Ripley chora a morte de Newt. Depois vê a corrosão do ácido na câmara de hipersono e diz a Clemens que tem de ver o corpo da criança. Numa outra cena, Clemens pergunta-lhe se Newt era sua filha e Ripley responde que não, depois de uma breve hesitação.

Um dos prisioneiros encontra Spike, o cão que revela marcas do face bugger, ficando a saber-se que o animal é um hospedeiro e que o alien está prestes a atacar.

A gaveta da morgue onde se encontra o corpo de Newt está assinalada com um pequeno ramo de flores secas, um toque de cor num ambiente sombrio, que leva o espetador a interrogar-se de onde poderiam ter surgido flores num planeta tão hostil, mas que revela a humanidade de Clemens. Ripley pede um momento a sós com o corpo e inspeciona-o. No fim, insiste 
com Clemens em fazer uma autópsia. Clemens afirma que a causa já é conhecida, mas Ripley é persistente, justificando com um possível contágio de cólera. Clemens concede. No decurso da autópsia, Ripley pede que abra o peito da jovem com cuidado. O pedido tem uma dupla leitura: cuidado pela fragilidade do corpo e cuidado pelo perigo que ele poderá conter. Mas nada acontece. Não há suspense nem falso engodo. O peito é aberto e Clemens mostra pulmões cheios de líquido. A penumbra da morgue realça os hematomas do rosto de Ripley e o seu sofrimento pessoal. Quando Clemens lhe pergunta o que estão, afinal, a procurar, a porta da morgue é aberta e entra o superintendente e o seu ajudante. Além de Clemens, Frank, o homem que resgatou Ripley dos destroços do salva-vidas, e Spike, o cão, até ao vigésimo minuto não existe ainda uma noção dos personagens nem da hierarquia em Fiorina.

Clemens explica ao superintendente que foi realizada a autópsia ao corpo da criança no interesse da saúde pública, afastando-se assim a possibilidade de doença contagiosa. Ripley intervém para dizer que é necessário cremar os corpos. O superintendente responde que serão conservados em gelo até a equipa de salvamento chegar. Ripley menciona a questão da saúde pública e a vaga possibilidade de uma contaminação por cólera ter de constar dos relatórios é suficiente para convencer o superintendente da necessidade da cremação. O momento é aproveitado para dar a caracterização dos habitantes de Fury: vinte e cinco condenados, todos com duplo cromossoma Y, ladrões, assassinos, violadores e pedófilos. O confronto deste filme não será com tripulantes de uma nave nem com marines treinados e armados, como em Aliens - O Reencontro Final, mas criminosos violentos que a sociedade rejeitou, convertidos a uma qualquer fé, sem higiene, sem tecnologia, sem armas e sem esperança, presos num planeta hostil de onde não podem fugir.

Ripley não refere a necessidade de autopsiar Hicks, embora ele pudesse ser igualmente hospedeiro, nem é mencionada a questão de saber se ou como um corpo morto poderia albergar um hospedeiro. Excluída Newt por autópsia, Bishop por ser sintético e Hicks por não ter sido sequer considerado, o espetador, confrontado nos minutos iniciais pela imagem radiográfica de um crânio a ser envolvido pelos dedos ou garras do face hugger, sabe desde já que Ripley é portadora de um alien. 
A cena seguinte passa-se nos fornos onde será feita a cremação. Pela primeira vez nos três filmes da série, é feita uma cerimónia semelhante a um funeral religioso. No primeiro filme, Kane é lançado no espaço sem palavras nem manifestações de dor. No segundo existe a dor da perda dos camaradas de armas, mas nunca a dimensão ritualista de um funeral. Agora é fornecido sofrimento perante a morte, ainda que nenhum dos homens tenha conhecido Hicks ou Newt.

Imagens do funeral alternam com imagens do cão, que se agita. O superintendente lê palavras de um livro sagrado e a montagem de Fincher vai fundindo os rostos pesarosos dos homens. Uma das imagens é um grande plano de Clemens, Ripley e do superintendente, os três alinhados com a mulher ao meio. O significado da imagem não é, nem denotativa nem conotativamente, claro, mostrando-se irrelevante para as dinâmicas de poder e para os eventos que se seguem.

O superintendente termina a cerimónia com a frase "és pó e ao pó voltarás", enquanto a sombra de Spike, o cão, se projeta nas paredes sombrias da divisão em que se encontra. Dillon, o pregador, intervém e o que diz, entrecortado com as imagens do cão a ganir de dor, causa impacto emocional no espetador. "Porque é que os inocentes são punidos?" pergunta Dillon, "Porquê o sacrifício? Porquê a dor?", interroga-se, enquanto o cão se contorce em agonia. Ripley deixa correr uma lágrima pelo rosto enquanto Dillon refere que Newt não conhecerá o sofrimento daqueles que ficam para trás. Os corpos de Newt e Hicks mergulham, não na escuridão do espaço, mas no metal incandescente das fornalhas, enquanto Dillon continua o seu sermão. O cão rebenta em sangue e do nariz de Ripley corre também um fio de sangue. Ao contrário do alien que rebentara o peito de Kane numa forma embrionária, este alien nasce já num estado quase adulto, envolto nas vísceras de Spike, enquanto na fornalha os homens ouvem Dillon proclamar uma nova vida, um novo começo. O monstro recém-nascido equilibra-se nas suas pernas e dá o seu primeiro vagido, ao mesmo tempo que os homens respondem "Ámen" às palavras de Dillon. A cena é simultaneamente um ritual de morte e de vida, uma celebração espiritual com impacto cinematográfico, embora o seu sentido metafórico seja ambivalente. 
A cena seguinte é de Ripley, na casa de banho, já com o cabelo cortado, o que não deixa de ser surpreendente uma vez que, dada a trivialidade do motivo, o ato de cortar o cabelo ou de deixar que Clemens o fizesse provocaria no espetador mais impacto do que vê-la simplesmente sem ele. Toma banho enquanto Clemens vigia a entrada e se ouvem os comentários dos homens sobre o facto de ela ser mulher. Também neste filme há uma cena de messe, usada como dispositivo para dar a conhecer as personagens e suas hierarquias e relações. Clemens explica com mais detalhe a história e estrutura social das instalações. Numa posição mais elevada, um dos prisioneiros assiste à conversa, reforçando a ideia de vigilância, falta de privacidade e necessidade de um mecanismo de controlo de boatos. Conta que os prisioneiros abraçaram a religião, um tipo de cristianismo apocalíptico e fundamentalista, e decidiram ficar no planeta quando a Companhia quis fechar as instalações. A Companhia designou também dois responsáveis e um médico para os acompanhar. Ripley pergunta-lhe como conseguiu o cargo, Clemens foge à questão, interrogando-a sobre como se sente com o novo corte de cabelo. Do mesmo modo, quando Clemens interroga Ripley sobre os verdadeiros motivos que a levaram a pedir a autópsia, esta responde perguntando-lhe se ele se sente atraído por ela, antecipando a relação íntima que se irá estabelecer entre os dois.

A ação passa para os túneis das instalações. O ambiente é degradado, sujo e mal iluminado. Um dos prisioneiros limpa o teto perto de um ventilador, enquanto canta. O homem pisa uma coisa estranha, que pode identificar-se como pele largada pelo alien na sua metamorfose, que não deveria existir, visto o alien ter irrompido de Spike já numa forma adulta. Enquanto o prisioneiro explora a pele é atacado pelo alien e o seu corpo mutilado escorrega até ao ventilador.

A imagem do sangue nas pás do ventilador e nas paredes dá lugar a Ripley, que acorda sobressaltada. Deitado a seu lado está Clemens, cuja nuca está tatuada como a dos restantes prisioneiros. Clemens levanta-se e agradece-lhe o afeto. Ripley pede explicações para o código de barras tatuado na nuca, mas ele guarda a explicação para mais tarde.

Pela primeira vez na série gera-se um clima romântico, concretizado numa relação física. No filme anterior, com Hicks, criara-se um clima de 
confiança mútua sem intimidade física. Com Clemens, existe a intimidade física sem que se estabeleça confiança entre os dois. Nenhuma das duas personagens confia suficientemente na outra para contar os seus segredos. O suspense quanto às razões que levaram Clemens àquele local é um dispositivo a que é dada muita atenção, mas de reduzido impacto narrativo atendendo à relativa trivialidade da revelação. Quanto às razões de Ripley, essas são partilhadas com o espetador. Apenas Clemens as desconhece, sem justificação clara para isso, tornando-o um alvo desprotegido.

Ripley volta ao salva-vidas da Sulaco. Clemens surpreende-a e avisa-a que irritará Andrews se continuar a andar pelas instalações sem escolta. Ripley pede para que lhe conte o que ocorreu e ele concede, explicando que um dos prisioneiros foi morto numa conduta de ar, sugado por uma ventoinha de três metros. Conta também que encontrou uma marca igual à do tubo de criogénio do salva-vidas. Ripley mostra-se preocupada e Clemens pergunta novamente o que se passa, afirmando que está do seu lado. Ripley não responde e pede que lhe arranje um computador. Se restassem dúvidas quanto ao anacronismo das instalações, Clemens diz que não têm nada desse género. Ripley lembra-se que poderá usar Bishop e Clemens diz onde o poderá encontrar. A cena seguinte é no gabinete de Andrew e, mais uma vez, é evidente o antagonismo existente entre os dois homens. Andrews recrimina Clemens por ter deixado Ripley sair da enfermaria, uma vez que recebeu uma mensagem na rede informática, a primeira comunicação de nível superior recebida em Fiorina, avisando que Ripley é prioridade máxima e que deve ser bem tratada. Ameaça também contar a Ripley a história sórdida de Clemens, deixando no ar mais uma vez o suspense relativamente ao seu passado e às razões que o levaram a Fury 161.

Ripley encontra os restos de Bishop numa lixeira. De regresso ao interior das instalações, é barrada por prisioneiros que se preparam para a violar. Dillon intervém e salva Ripley, que agride um dos seus atacantes antes de ir embora. Esta cena antecede o primeiro confronto com o alien, ilustrando que o perigo humano não deve ser negligenciado.

Num outro espaço das instalações, alguns condenados trabalham à luz de velas e archotes. Depreende-se que tentam calcular o tamanho do compartimento. Uma das velas apaga-se. As velas assinalam o caminho de regresso, 
por isso um dos homens volta para acender as que se apagam. No percurso, é atacado pelo alien. Os companheiros veem e fogem. Correm pelos túneis sem que tenham uma noção clara de onde estão. Um segundo homem é atacado. É morto perante o companheiro que assiste, enquanto um jato de sangue o atinge no rosto. A imagem do seu rosto ensanguentado dá lugar à imagem triunfante do alien, de braços abertos.

O corpo decepado de Bishop, também de braços abertos, é atirado para a mesa no ambiente mais assético da enfermaria. Ripley trabalha sobre Bishop e, em poucos segundos, consegue ligá-lo. Pede-lhe para aceder aos registos de bordo da Sulaco. Bishop repete os acontecimentos iniciais. Apesar das evidências do ácido no tubo criogénico, Ripley pergunta a Bishop se havia algum alienígena a bordo. Bishop anui e Ripley pergunta se estava na Sulaco ou se veio no salva-vidas. Bishop responde que esteve sempre com eles. Ripley pergunta se a Companhia sabe. A resposta de Bishop é que a Companhia sabe tudo o que se passou na nave. A omnipresença do alien e da Companhia restabelece as duas relações de antagonismo presentes em toda a série. Bishop pede para Ripley o desligar. Poderia ser reconstruído mas nunca voltaria a ser topo de gama, por isso prefere não existir. Ripley desliga-o, cortando a última ligação ao filme anterior.

Dois homens carregam para a enfermaria o prisioneiro sobrevivente, que balbucia coisas ininteligíveis, falando do alien como sendo um dragão. Dillon, Clemens, Andrew e Aaron estão presentes e discutem o que fazer com o condenado. Ripley ouve os homens falar. Abre as cortinas e revela-se, pronta a contar a verdade. Clemens olha-a, inquiridor. Ripley pede então para falar com Andrews e este concede-lhe uma audiência. Andrews pergunta a Ripley se espera que ele acredite na história que ela lhe conta. Ela interroga-o sobre o tipo de armas que têm. Andrews responde que se trata de uma prisão e, por isso, não há armas. Ripley interroga-se como é que uma prisão de segurança máxima não possui armas de nenhum tipo e Andrews responde que há algumas facas e machados. O superintendente manda-a de volta à enfermaria, onde ficará de quarentena, a salvo de feras grandes e más.

Já na enfermaria, Ripley pergunta a Clemens se não há fuga possível do complexo. Nenhum dos dois pede ou dá explicações, nem Ripley alerta 
Clemens para o perigo ou se preocupa em fazer planos para a batalha que se adivinha. Bebem de uma chávena com aparente serenidade e Clemens informa-a de que uma nave de resgate a virá buscar em breve. Quando finalmente lhe pergunta sobre o que ela e Andrews conversaram, ela responde que não lhe dirá porque ele a julgará louca. Ripley tosse. Clemens pergunta como se sente e ela explica que tem a garganta dorida, enjoos e que está furibunda. Clemens oferece um dos seus cocktails médicos. São interrompidos por Golic que, numa reflexão filosófica, diz não saber porque é que toda a gente culpa toda a gente. "Ninguém é perfeito", diz o condenado, "apenas humanos. Não existe tal coisa como um humano perfeito". O monólogo, relativamente inconsequente, continua com a afirmação de que num mundo louco um homem são deve parecer louco, o que pode ligar-se à afirmação de Ripley de que Clemens a julgaria louca se ela contasse a verdade. Golic pergunta a Ripley se é casada e, sem esperar resposta, diz-lhe que deveria casar e ter filhos. E depois afirma que também ela vai morrer. Nesse momento, Clemens fecha a cortina e pede-lhe a resposta para a pergunta que o prisioneiro lhe fizera, enquanto prepara a seringa. Ela responde que não é casada e pede que Clemens conte a sua história. O médico acede e conta que nos anos iniciais da sua carreira era um médico promissor. Durante o seu primeiro internato, fez um turno de trinta e seis horas. Quando saiu, bebeu demais, mas foi chamado de volta e acabou por matar onze dos trinta feridos de um acidente numa fábrica, receitando a dose errada de analgésicos. Cumpriu uma pena de sete anos em Fiorina. Quando o grupo decidiu ficar, ele ficou também. Clemens pergunta a Ripley se ainda confia nele com uma agulha e ela estica o braço, sorrindo, para que ele a injete.

Mas a banda sonora começa a assinalar que algo vai acontecer. Vislumbra-se o reflexo de um vulto numa superfície metálica e Golic agita-se, enquanto o êmbolo da seringa desce. Os contornos do vulto assumem forma e o alien ataca Clemens no momento em que este retira a seringa do braço de Ripley. O rosto do alien enche o ecrã. O segundo conjunto de dentes projeta-se, perfurando o crânio de Clemens.

Ripley está sentada no chão, com a cabeça encostada aos azulejos da enfermaria. O alien aproxima-se, abre a boca com os dois conjuntos de dentes, 
o líquido a escorrer, e afasta-se. Esta foi a imagem escolhida para promover o filme, sublinhando a fragilidade de Ripley perante a ameaça que o alien constitui. Mas o alien não a mata.

Ripley corre pelos corredores. A ligação à cena seguinte é feita pela voz de Dillon que, na messe com os outros prisioneiros, pede a Deus para lhes dar forças. O superintendente faz o controlo de rumores, expondo os factos relativos à morte dos prisioneiros. Ripley chega no momento em que Andrews prepara uma equipa de buscas. Alerta os homens para o perigo do alien e Andrews tenta calá-la, pedindo a Aaron para a levar de volta à enfermaria. Nesse momento, Andrews é apanhado pelo alien, que o leva por uma conduta do teto. O alien deste terceiro filme é retratado como um assassino, à imagem dos homens que mata. Parece não haver qualquer intenção de incubar e as mortes são mais violentas e explícitas.

Um prisioneiro limpa o sangue do chão enquanto a voz de Dillon anuncia que se aproxima o dia do juízo final. Os homens rezam. A questão da liderança coloca-se. Os prisioneiros tentam que Dillon assuma o comando do grupo, mas este recusa, argumentando que só sabe tomar conta de si próprio. O argumento não parece muito sólido, uma vez que em todas as cenas anteriores Dillon assumiu protagonismo como porta-voz e líder incontestado do grupo.

O combate prevê-se difícil: não há armas nem circuito de vídeo, e não se podem selar áreas, o que impede o recurso às estratégias utilizadas nos outros filmes da série. A planta das instalações mostra uma conduta de ventilação que vai do refeitório à enfermaria. Ripley diz que o alien ficará perto deles, como o leão fica perto das zebras. O plano proposto por Ripley é atraí-lo para um contentor de lixo tóxico que nunca havia sido usado, a única divisão estanque das instalações. Para isso dispõem apenas de archotes e quinitricetilina, um líquido inflamável e explosivo.

Aaron, Dillon e Ripley, os três líderes do grupo expõem o plano. Os homens resistem mas acabam por aderir. Começa a preparação. O chão e as paredes são embebidas com quinitricetilina, enquanto o alien se mantém convenientemente à distância. Dillon e Ripley espalham líquido no chão e Dillon pergunta se ela tem sentido saudades de Clemens, mostrando conhecimento da sua intimidade. A cena termina com Ripley a denotar sinais 
de cansaço e mal-estar, alternando com imagens dos prisioneiros, que entretanto passam por vestígios do líquido viscoso do alien. Um dos homens, que sobe por uma das escadas para os túneis de ventilação, deixa cair um bastão e desce para o apanhar. Quando volta a subir, o alien está à sua espera. O balde e o bastão caem em câmara lenta, provocando uma explosão que alastra por corredores e tubos de ventilação, atingindo os prisioneiros. Dillon encontra um dispositivo na parede, supostamente para ativar os extintores de teto, mas não funciona. Manda um dos prisioneiros, Jude, ir ativar os extintores. O homem corre pelos corredores. Um dos colegas alerta-o para a presença do alien atrás de si. Todos se reúnem no túnel. De um lado está Jude, do outro os restantes sobreviventes, e o alien no meio. O fogo continua a arder nas paredes. Ripley agarra uma tocha e tenta chamar a atenção da criatura. Jude, num ato de heroísmo, começa a correr e desafia o alienígena para o apanhar. O ser segue-o e Ripley vai atrás, com os homens a segui-la. Fecham a porta do contentor de resíduos e aprisionam o alien. Dillon parte o dispositivo ao lado da porta, conseguindo finalmente ativar os extintores.

A imagem dos homens a avançar em câmara lenta, debaixo da chuva dos aspersores e com chamas ainda acesas nas paredes, alguns encapuçados, a escolha de canto gregoriano para banda sonora e o plano seguinte, do torso de Dillon, de mãos levantadas, numa liturgia em memória dos companheiros mortos, são claramente alusivos à vida monasterial proposta em argumentos anteriores.

Enquanto assistem à cerimónia, Ripley pergunta a Aaron se é religioso e ele responde que não, justificando com o facto de ter um emprego. Diz a Ripley que a equipa de resgate chegará em poucos dias e que eles matarão o alien aprisionado no contentor. Na enfermaria, Golic está ainda preso no colete de forças. Pede a Morse, o prisioneiro encarregue de o vigiar, que o liberte para que o dragão não o apanhe. Morse recusa e diz-lhe que têm o dragão encurralado, mas acaba por ceder, libertando-o e dizendo onde está o alien. Golic diz que tem de voltar a ver o monstro e bate em Morse, deixando-o inconsciente. Entretanto, Aaron e Ripley estão no centro de comunicações a decidir a mensagem que enviarão para a equipa de resgate que vem a caminho. Ripley escreve no ecrã que encurralaram o xenomorfo 
e pede permissão para o exterminarem. A resposta é imediata. No ecrã, lê-se que a chegada da equipa será às doze horas e que a permissão para exterminar o alien é negada.

Golic aproxima-se do compartimento onde está aprisionado o alien. Pede ao guarda que o deixe entrar. O guarda recusa, mas Golic aproxima-se e olha fascinado para a porta. Depois pede desculpa e, num movimento rápido, corta a garganta do outro prisioneiro. Durante um instante, grita histericamente, num comportamento pouco adequado a um assassino de duplo cromossoma Y, e depois avança em direção à porta. Abre-a, revelando a escuridão do compartimento, e fala para o seu interior, pedindo para que lhe seja dito o que deve fazer a seguir. Entra reverentemente, a dimensão religiosa sublinhada pelo curvar do corpo, o fechar das mãos e a música coral que serve de banda sonora. A imagem que se segue é a do alien a correr livremente pelas portas abertas do compartimento que o continha.

Dillon e Ripley conversam enquanto Dillon brinca com uma escova de dentes. Ela explica que a equipa de resgate vai levar o alien consigo e não o vai matar. Dillon aparentemente não se incomoda com isso e Ripley argumenta que muitos inocentes vão morrer, apelando à compaixão que a sua religião proclama. A conversa é interrompida por Morse, que lhes comunica que têm um problema. De regresso ao contentor de resíduos, descobrem o corpo do guarda no chão. Morse e Aaron discutem e Ripley encosta-se à parede. Abre e fecha as mãos, num movimento que faz lembrar os dedos do face hugger. Comunica que tem de ir ao vaivém e prepara-se para fazer uma tomografia. Aaron oferece a sua ajuda. No ecrã, surge o interior de Ripley. O computador deteta um tecido estranho. Aaron diz-lhe há um alien dentro dela. A imagem, embora difusa, mostra-o na sua fase larvar, semelhante ao chestburster. Ripley pede a Aaron para enviar uma mensagem à equipa de resgate a dizer que há contaminação. Aaron argumenta que, desse modo, a equipa voltará para trás e Ripley confessa que esse é o objetivo, porque se o ser sair do planeta matará tudo e a Companhia não se preocupará com isso. Aaron não se deixa convencer. Quer ser salvo. Diz ter mulher e filha e querer voltar para casa. Não dá o código a Ripley, que avança para o atacar fisicamente. Aaron afasta-se e Ripley vira costas. Aaron pergunta-lhe onde vai e ela responde que talvez vá ter com 
o alien para avaliar até que ponto ele é esperto, e que tem uma ideia onde ele está: "lá em baixo, na cave". Aaron não percebe a dimensão metafórica e responde, numa caracterização correta, que todo aquele lugar é uma cave.

Quando Ripley se afasta, aparece no computador a mensagem de que a tomografia foi recebida e que a chegada da equipa médica está prevista para daí a duas horas, lembrando o que Bishop dissera acerca de tudo ser transmitido à Companhia. Aaron senta-se e lê uma segunda mensagem que diz ser prioridade máxima manter Ripley em quarentena até a chegada da equipa. O ecrã do computador onde estão escritas as palavras "à espera de resposta” dá lugar à escuridão do espaço, onde se vê uma nave em movimento.

Ripley procura a criatura. Há imagens, tenuemente iluminadas pela luz da lanterna, de tubagens com água, vapor, pó e teias de aranha. Ripley fala para o alien, dizendo que faz parte da família. Agarra uma barra de ferro e continua a caminhar no interior de uma divisão empoeirada e escura. Quando avista o que lhe parece ser o alien, diz-lhe que faz parte da vida dela há tanto tempo que já não se lembra de mais nada. Pede para a matar e ataca-o, mas afinal é apenas um tubo cheio de insetos. É do teto que desce o alien e o seu corpo enche o ecrã deixando-o escuro. O suspense não é prolongado. Na imagem seguinte, Ripley conta a Dillon que o alien não a mata porque ela tem uma rainha dentro dela. Não é explicado como é que Ripley sabe que se trata de uma rainha. Não há qualquer referência anterior ao que poderá tê-la conduzido a essa conclusão, nem a mera avaliação lógica dos acontecimentos leva a isso, o que fragiliza a narrativa.

Ripley pede a Dillon que a mate. Convence-o facilmente e coloca-se em posição sacrificial, usando uma grade para se apoiar. A imagem de Ripley de braços abertos, com a cabeça entre as grades enche o ecrã. Pede para que não faça orações. O impacto da cena é profundo, antecipando a dimensão religiosa da morte de Ripley. No entanto, Ripley preparava-se para morrer sem fornecer a Dillon qualquer detalhe de como nasce o alien e se este poderá sobreviver num corpo morto, não tomou qualquer providência para garantir que a rainha seria destruída quando irrompesse do seu peito, nem deu indicações sobre os cuidados a ter com os seus restos mortais. A posição simbólica em que tencionava morrer permitiria que a rainha 
escapasse por entre as grades sem que Dillon o pudesse evitar, ameaçando assim a humanidade que ela estava disposta a salvar.

Dillon desfere um golpe de machado, não contra Ripley mas contra as grades, decisão que contraria quer o instinto homicida quer o espírito religioso que proclama. Justifica-se dizendo que precisa de Ripley para apanhar o monstro. Fica entre os dois o acordo de que Dillon tratará dela quando chegar o momento, providenciando uma morte rápida, fácil e indolor, promessa que se revela vã.

Dillon reúne novamente os homens, incitando-os à luta. O ambiente desolador de fábrica abandonada, com tubagens ferrugentas, vapor a correr e água a pingar, acentua-se. Uma inscrição asiática aparece na parede por detrás de Aaron, o homem da Companhia. Este apela a que se espere pela equipa de resgate. Dillon faz um dos seus discursos mobilizadores, enquanto Ripley lhes diz que a equipa de resgate não se preocupará com eles, como não se preocupou com a tripulação da Nostromo e os marines da Sulaco. Tratando-se de uma fundição, o novo plano é atrair o monstro para a fornalha e afogá-lo em chumbo, usando os homens como isco.

As funções são distribuídas. Para tornar a situação mais dramática não há certezas de que os instrumentos da fornalha ou as portas que servirão para proteger os homens funcionem. A ação começa. A câmara vai assumindo o ponto de vista do alien sempre que este persegue os homens, alternando com tomadas de imagem normais que dão a posição relativa de cada prisioneiro.

Os homens vão sendo mortos enquanto um satélite é ajustado e uma nave se aproxima do planeta. A equipa de resgate aterra no solo ventoso de Fury 161 e dirige-se às instalações. Dillon salva um dos homens e conduz o alien até Ripley. Os pistões são ativados, mas a criatura afasta-se, obrigando-os a tentar atraí-la de novo. A equipa de salvamento está já no interior das instalações. Homens vestidos com fatos de proteção brancos interrogam Aaron sobre o paradeiro de Ripley.

Morse e outro prisioneiro colidem nos túneis e caem. Depois de um momento de descompressão, em que riem por estarem salvos, o alien ataca e mata um deles. Morse afasta-se, rastejando, e Ripley aparece, tentando atrair novamente a criatura. Dillon avisa que estão a ficar sem 
tempo. Ripley agarra a cauda do monstro e puxa-o. Dillon vem ter com ela. Juntos conseguem conduzi-lo à fornalha e Morse fecha a porta. O alien é encurralado.

A equipa de salvamento avança, passando pelo refeitório. Ripley, Dillon e o alien encontram-se no espaço limitado onde o metal líquido deve ser vertido. Dillon obriga Ripley a subir, apesar de ela argumentar que quer morrer. Ele lembra-a que têm um acordo: primeiro morre o monstro, depois ela, mas Dillon fica para que o alien não a siga. O chumbo é derramado sobre o alien, que entretanto ataca Dillon.

Morse ri vitorioso, mas o alien emerge do chumbo num salto. Persegue Ripley pela escada e Morse diz-lhe para ligar os aspersores. A água faz explodir o ser, que voa em pedaços entre o fumo da fundição. Este fenómeno, anteriormente estabelecido com a imagem de um balde de ferro a quebrar sob efeito da água dos aspersores em metal quente, não é correto do ponto de vista científico, uma vez que água fria sobre metal quente faz com que este arrefeça e solidifique, não que quebre como o vidro.

Morse conduz a plataforma giratória em que se encontra até Ripley. A equipa de salvamento entra na divisão. Ripley diz-lhes para ficarem onde estão e não avançarem. Na realidade, não se encontra em posição para fazer este tipo de ameaça. O único homem que não está vestido de branco tira os óculos e revela o rosto de Bishop. Pergunta-lhe se sabe quem ele é. Ripley diz que é um androide enviado pela Companhia. Ele apresenta-se como o humano que criou Bishop, enviado para que ela pudesse ver um rosto amigo e saber o quão importante é para a Companhia. Diz-lhe que querem matar o ser e levá-la de volta, argumento em que nenhum espetador acredita. Neste ponto do filme os diálogos seriam claramente dispensáveis, uma vez que foi estabelecido ao longo de toda a série que os interesses de Ripley e da Companhia são antagónicos e irreconciliáveis. Mas, ainda assim, Bishop faz Ripley vacilar prometendo-lhe uma vida calma na Terra, sem alien e com filhos, o que Golic já referira dever ser o sonho de qualquer rapariga bonita. Depois de ter aproximado o conceito do alien do de besta, de demónio, Bishop aparece agora como personagem de uma outra metáfora cristã, o Diabo que tenta Cristo antes da sua morte, sublinhando a dimensão sacrificial da morte de Ripley. 
Ripley hesita mas não se deixa tentar e fecha o gradeamento da plataforma enquanto Morse a afasta. Um dos membros da equipa de salvamento atira sobre Morse, atingindo-o na perna. Aaron ataca Bishop com uma peça metálica e é morto com vários tiros. Morse e Ripley afastam-se e Bishop, com uma orelha pendente que o denuncia como não humano, altera o discurso, aproximando-se do registo da admiração de Ash pela espécie. Morse trava a plataforma e Ripley, de rosto sereno, abre os braços e lança-se de costas sobre o metal incandescente. Quando mergulha, a rainha emerge do seu peito e ela segura-a junto a si num gesto que pode ser lido como maternal. O seu corpo mergulha, como o de Newt e Hicks, no metal fundido. Nos planos que se seguem, as chaminés de Fiorina desligam-se, o contorno do planeta ilumina-se, portas trancam-se e a equipa parte, levando Morse, o único sobrevivente de Fury 161. O filme encerra com imagens dos destroços do salva vidas e o relatório de Ripley na Nostromo, feito momentos antes de se deitar no compartimento de hipersono. O plano de três compartimentos alinhados e vazios, lembra o destino dos três sobreviventes da Sulaco e mostra a diferença radical entre este filme e os anteriores. A imagem final é de um ecrã onde se lê a situação de Fiorina: desativado, instalações seladas, sem prisioneiros e o equipamento de refinaria destinado a ser vendido como sucata. O ecrã desliga e os créditos finais rolam.

O terceiro filme, pelo atraso de produção e fragmentação de autoria, torna-se mais difícil de conter numa categoria analítica ou de apresentar um ângulo ou tema dominantes. Pode, no entanto, classificar-se como uma retrovisão: o futuro em Fiorina é um passado possível, anterior ou independente da tecnologia e da racionalidade científica, em que o alien já não é encarado como um ser biologicamente admirável, mas como uma entidade de contornos religiosos, violenta, quase castigadora.

Dos três filmes, este é o mais distópico. Fiorina, enquanto espaço de ação, é um planeta desolador, e o futuro assemelha-se a um passado medieval, de violência, loucura, doença e fé, dominado por instituições vigilantes e punitivas. O capital continua a assumir-se como poder, revelando o mesmo desprezo pelos indivíduos que já está presente nos filmes anteriores. 
A alteridade continua a ser um agente de destruição, uma entidade não tanto biológica mas religiosa, representando um demónio, uma gárgula, um poder superior, quase divino, que os humanos têm de enfrentar de forma sacrificial.

Além do vaivém da Sulaco, a tecnologia é praticamente inexistente e o computador parece rudimentar, servindo apenas para estabelecer comunicações com a Companhia. A única ciência é a medicina de Clemens e assemelha-se, na atividade e nos instrumentos, a uma prática oitocentista, anacrónica num futuro de viagens intergaláticas e colonização planetária.

Apenas Bishop, o androide, permite recuperar alguma iconografia da ficção científica e direcionar o filme para preocupações com a tecnologia. Porém, a existência de dois Bishop, um ao serviço dos humanos e outro ao serviço dos interesses da Companhia, cria alguma ambivalência em relação à tecnologia.

Dado o afastamento em relação às convenções do género e a descontinuidade com os filmes anteriores, Alien ${ }^{3}$ torna-se difícil de classificar e mesmo de analisar enquanto filme de ficção científica. Assumindo que o futuro é uma sombra do passado e que a tecnologia está praticamente ausente, a única novidade ficcional proposta é a alteridade, não como entidade biologicamente complexa ou socialmente organizada, mas como entidade demoníaca cujo único objetivo parece ser a satisfação do prazer de matar, a maldade num estado puro, livre de qualquer vestígio de humanidade. 
(Página deixada propositadamente em branco) 


\section{ALIEN - O REGRESSO}

bell gives birth!

A morte de Ripley, a ausência de armas ou tecnologia e o aparente fim da narrativa deixam as audiências mais fiéis à série Alien pouco satisfeitas. Mas, como refere David Thomson (1999:105), depois do filme número três não sobra nada para uma sequela e, nesta perspetiva, Alien $^{3}$ é simultaneamente destrutivo e drasticamente inovador.

No seu primeiro lançamento nos Estados Unidos da América, o filme fez cerca de trinta e dois milhões de dólares de bilheteira, no ano em que Batman Returns ultrapassou os cem milhões. No estrangeiro, conseguiu melhores bilheteiras e teve melhores críticas, sendo interpretado como uma metáfora à SIDA ou como resposta ao aumento do sentimento religioso. Foi também nomeado para o Óscar de melhores efeitos visuais, tendo perdido para A Morte Fica-lhes Tão Bem (Zemekis, 1992).

Por esta altura, a 20th Century Fox já licenciara a marca Alien para comics, brinquedos e outros jogos e, apesar do fracasso do terceiro filme, começa a falar-se em continuar a sequela.

O quarto filme continuou a ser uma produção da Brandywine para a 20th Century Fox, mas com maior controlo por parte do estúdio. Jorge Saralegui, um jovem produtor da Fox, ficou responsável por dar continuidade à história. Face à relutância inicial de Sigourney Weaver, Saralegui trabalhou numa ideia de filme em que um clone de Newt tomaria o lugar de Ellen Ripley. Para escrever esse argumento, Saralegui contratou Joss Whedon, mas a ideia de que Sigourney poderia embarcar no projeto fez surgir um guião diferente. 
Sigourney aceitou fazer o quarto filme por onze milhões de dólares, o cargo de produtora executiva e o poder de veto na escolha do realizador. Para realizar o filme foram abordados Danny Boyle e David Cronenberg, entre outros, que declinaram o desafio por considerem demasiado pesada a herança dos filmes anteriores. Até que Saralegui se lembrou do francês Jean-Pierre Jeunet.

A história proposta por Whedon e Jeunet dá continuidade aos filmes anteriores: não ignora a morte de Ripley, mas devolve-lhe a dimensão maternal e heroica que Cameron lhe atribuíra. Além de Sigourney no papel de Ellen Ripley/clone número oito, o elenco conta com Winona Ryder como Call, Dominique Pinon como Vriess, Ron Perlman como Johner, Gary Dourdan como Christie, Michael Wincott como Frank Elgyn, Kim Flowers como Sabra Hillard, Dan Hedaya enquanto General Martin Perez, J.E. Freeman como Mason Wren, Brad Dourif como Jonathan Gediman, Raymond Cruz como Vincent Distephano, Leland Orser como Larry Purvis e Marlene Bush no papel de cientista não nomeada.

O genérico inicial do quarto filme não corre sobre o escuro do espaço, mas sobre tecidos vivos em formação. Carateres humanos e alienígenas fundem-se no ecrã numa espécie de jogo de espelhos. Como notam Gallardo e Smith (2004:162), a exploração do espaço torna-se, neste filme, a exploração do corpo a nível molecular, embora se possa referir que os filmes Alien nunca foram acerca da exploração do espaço exterior.

Estabelecida a continuidade com o filme anterior nestas primeiras imagens de engenharia genética, é fornecida a imagem exterior da USM Auriga, nave de pesquisa médica da United Systems Military. Uma das portas da nave abre e veem-se dois guardas armados que protegem uma outra porta, que se abre com o avanço da câmara, para revelar um laboratório onde dois cientistas de bata branca trabalham. Gallardo e Smith (id.:160) chamam a atenção para alguns detalhes da imagem dos guardas, como o facto de terem as armas apontadas um ao outro e mascarem chiclete, sublinhando o tom de paródia do filme de Jeunet.

No interior de um compartimento circular, uterino, a proteção metálica de um contentor em vidro, também ele cilíndrico, tubiforme, sobe e revela uma criança nua. Em off ouve-se a voz de Ripley que repete a frase de 
Newt: "A minha mãe sempre disse que não havia monstros, mas há"8. O plano do rosto de criança dissolve num plano do rosto de Ripley e a câmara afasta-se, revelando o corpo nu num compartimento transparente, com os cientistas a observá-la. Um deles diz que ela é perfeita.

Cientistas operam o corpo de Ripley adulta, através de um vidro de proteção, retirando o alien que está no seu interior. Ripley sobrevive e, perante a questão de saber o que fazer com a hospedeira, um dos cientistas diz para voltarem a cosê-la.

Na cena seguinte o corpo de Ripley jaz no fundo de uma divisão circular, de tom ferroso e baço. Liberta-se de uma espécie de saco ou membrana plástica em que está envolvida. Metaforicamente, o lento romper do material envolvente pode ser entendido como um nascimento, mas o saco serve também para conter resíduos, lixo, aquilo que Ripley representa para os cientistas depois da extração bem sucedida da rainha. Ripley explora o seu corpo. No peito tem uma cicatriz, as unhas são pretas e no braço está tatuado o número oito. Simbolicamente, o número está associado à regeneração e equilíbrio de forças opostas e, deitado, representa o infinito, a ausência de fim, adequado ao processo de ressurreição.

Ripley é estudada pelos cientistas. Aparece com as mãos presas atrás das costas, com um colete de forças e uma postura displicente, abanando-se na cadeira como uma criança desinteressada. Imagens suas são mostradas a um militar, o General Perez, como sendo extraordinário o seu funcionamento humano normal. O General lembra que as suas memórias são as da mulher que conseguiu exterminar a espécie que eles recriaram e sugere matá-la. Os cientistas conseguem demovê-lo, mas Perez garante que a matará se ela der algum tipo de problemas, uma vez que não passa de um subproduto daquilo que verdadeiramente interessa. Esta conversa decorre enquanto os três homens percorrem o caminho que separa Ripley da rainha alienígena. Quando param, uma tomada de imagem triangula os três homens, colocando o militar em primeiro plano e os dois cientistas alinhados na retaguarda. Perez diz que a rainha, que está do outro lado do vidro protetor,

\footnotetext{
8 Tanto se poderá entender a frase como uma referência aos aliens, à própria monstruosidade de Ripley ou como dirigida aos cientistas que a observam.
} 
é que é importante. O alien é mostrado pela primeira vez, já no estado adulto, grande, brilhante, metálico, o seu caráter majestoso acentuado por uma estrutura morfológica em forma de coroa.

Na messe, local que nos últimos filmes serviu o propósito de apresentar as personagens e estabelecer hierarquias e dinâmicas relacionais, Ripley come com Gediman, o cientista responsável pela sua operação. Neste filme, a cena da messe serve para dar a conhecer o processo de construção da nova Ripley, fisicamente semelhante à anterior, mas assumidamente diferente. Ripley pergunta a Gediman como a fizeram e ele explica que usaram as amostras de sangue recolhidas de Fury 161 para a clonar. Wren junta-se a Ripley e a Gediman e explica que a United Systems Military substituiu a Weyland-Yutani depois de ela falir. Garante a Ripley que a USM não é uma empresa gananciosa e que as coisas mudaram muito em duzentos anos. Os interesses capitalistas, representados pela Companhia nos filmes anteriores, é agora substituído pelo complexo científico-militar, que assume o mesmo desprezo pela vida humana. Ripley garante que não fará qualquer diferença qual é a empresa. Morrerão todos na mesma.

Thomson (1998:163) repara que, sendo a clonagem o melhor dispositivo para trazer Ripley de volta, não existe qualquer razão plausível para que isso só aconteça duzentos anos depois da sua morte em Fiorina. Segundo ele, Ripley poderia ter sido clonada pela Companhia logo após a sua morte, não fazendo muito sentido que as amostras de ADN tivessem ficado duzentos anos à espera que alguém tivesse a ideia de recriar o alien e ainda menos sentido que isso se devesse ao apuramento científico das técnicas de clonagem.

Uma outra nave aproxima-se da Auriga. A informação aparece no ecrã: nave comercial Betty; tripulação: seis passageiros não registados. O interior tem um ar velho e low tech. A tripulação é apresentada. São irreverentes, marginais e pouco mobilizadores da simpatia da audiência. Elgyn, o capitão, provoca e acaricia Hillard, a mulher que pilota a nave. O seu código de autorização para aterrar a bordo da Auriga é um infantil EAT ME; Vriess conta anedotas eróticas a Call, Christie prepara-se para ir a bordo da Auriga com armas escondidas, Johner diverte-se atirando uma faca às pernas 
incapacitadas e insensíveis de Vriess e Call parte a faca de Johner. Apenas as mulheres inspiram alguma confiança e aparentam competência.

Vriess assobia a música de Popeye e Johner imita os sons de um macaco. Como refere Vriess, estaria na altura de começarem a conviver com melhor tipo de gente. A passagem para a imagem da Auriga a receber a Betty lembra que a tripulação irá, de facto, conhecer outro tipo de gente.

A USM Auriga dá as boas vindas aos tripulantes da Betty. Numa referência intertextual ao Mother, o computador da Nostromo, uma voz masculina informa-os que é Father, o computador da nave, e dá-lhes as instruções. A tripulação é revistada e Perez explica a Elgyn que o procedimento serve para evitar que algum deles se embebede e dispare uma bala contra o casco da nave. O tom utilizado pelos homens é indiciador de encontros e negócios anteriores. Seis molhos de notas são empurrados na direção de Elgyn. Perez refere que foram muito difíceis de encontrar porque já ninguém usa notas. Outro pormenor que dá um toque futurista à cena é a bebida que Perez serve, um cubo que se transforma em líquido por ação de um laser. Mas o conteúdo da conversa entre os dois homens é relativamente independente do período histórico em que decorre, com a sugestão de que a mercadoria transacionada será valiosa porque ilegal, e de que a Auriga estará a operar fora do espaço regulamentado. A mercadoria, oito humanos, é mostrada em recipientes cilíndricos, com amarras metálicas que os prendem à parede e um ovo alienígena em frente a cada um deles. Do outro lado do vidro, numa posição mais elevada, Gediman, Wren e a mulher cientista nunca nomeada, contemplam o abrir dos ovos e o processo de 'inseminação'. A cientista desvia o olhar horrorizada e Wren sorri quando um dos ovos abre e um dos humanos acorda e grita. Esta cena pode ser interpretada através de uma grelha de leitura de género, significando simultaneamente o apagamento das cientistas a que a história não deu nome, e a existência de uma maior sensibilidade e humanidade na construção feminina da ciência.

O plano é cortado para dar lugar a Ripley, que joga com uma bola de basquetebol num espaço que o espetador assume ser o ginásio da Auriga. Tripulantes da Betty entram e Johner disputa a posse da bola entre insinuações de caráter sexual. Ripley provoca-o e atira a bola por baixo das suas pernas, acertando-lhe nos genitais e agredindo-o com um murro que o faz 
literalmente voar pelo ginásio. Os outros tripulantes atacam-na. Hillard tenta agredi-la com uma bola, que Ripley agarra com a palma da mão. Christie agride-a na face com um haltere, provocando-lhe apenas um fio de sangue no nariz. Ripley desvia-se dos ataques seguintes e atinge-o na cabeça com a bola. Depois de neutralizar os atacantes, Ripley continua a lançar bolas para o cesto, perante o aplauso de Wren que, entretanto, entra no ginásio. Wren chama Ripley e assobia, confirmando a ideia de que estaria a treiná-la, como faria com um animal. Enquanto Ripley caminha em direção a Wren, inexpressiva, Johner interroga-se sobre o que é ela. Sem responder, virada de costas para o cesto e em andamento, Ripley atira a bola e encesta-a. Confirmando a sua sobre-humanidade, o pingo de sangue que caíra do nariz de Ripley borbulha no chão e mostra ser ácido, como o sangue do alien.

Começa uma sequência em que são mostrados os prazeres noturnos dos vários personagens: Elgyn massaja os pés de Hillard, Perez engraxa as botas, Vriess rouba peças do armazém, Christie, Johner e Call assistem a um programa televisivo sobre armas enquanto bebem e Gediman estuda os padrões de comportamento de três dos alienígenas. O seu fascínio faz com que imite os movimentos de cabeça de um deles. Quando o alien lança o seu segundo conjunto de dentes contra a divisória, assustando Gediman, este vinga-se carregando num botão que desencadeia o lançamento de gás. O ser prepara-se para um segundo ataque mas hesita ao ver a mão de Gediman sobre o botão, mostrando inteligência.

Call, aparentemente ébria, provoca uma manobra de diversão que justifica o afastamento dos companheiros e abre a cela de Ripley com um spray que replica o hálito de Perez. Prepara-se para atacar o clone, mas a cicatriz do peito fá-la parar. Ainda de olhos fechados, Ripley pergunta-lhe se afinal a vai matar ou não. Call responde que já não vale a pena e interroga-se sobre o motivo de a manterem viva. Ripley responde que o fazem porque ela é a última novidade. Call oferece-se para acabar com o seu sofrimento e Ripley conduz-lhe a faca, empalando a própria mão. Call pergunta quem é ela e o clone responde com o nome, graduação e número de Ellen Ripley. Call responde que Ripley morreu há duzentos anos e que ela é apenas uma coisa, um constructo, algo que foi feito num laboratório. A esse primeiro 
nível de infra-humanidade, Ripley acrescenta mais um, o da monstruosidade, afirmando que consegue sentir o alien por detrás dos seus olhos. Com mãos como garras, Ripley acaricia Call, avisando-a que é demasiado tarde para parar o alien ou para sair dali viva. A jovem responde que não se importa e é a vez de Ripley se oferecer para lhe fazer parar a dor, encostando a sua cara à dela num gesto de ternura. Um ruído faz com que Ripley largue Call e lhe diga para desaparecer. A rapariga sai, mas é apanhada por Wren que acusa os tripulantes da Betty de terrorismo. Elgyn tenta argumentar, mas Wren diz que, sabendo ou não, trouxeram uma terrorista para bordo da Auriga, por isso todos irão morrer. Mas os terroristas não se rendem. Perante um sinal de Elgyn, Christie saca das armas que levara escondidas e dispara sobre os guardas, Hillard desarma um, Johner transforma o seu termo numa arma e, em poucos segundos, todos os guardas são abatidos ou imobilizados.

Gediman vê o que se está a passar através dos ecrãs de vigilância e tenta alertar a segurança, sem conseguir. Enquanto se mantém afastado do botão que permite controlar os aliens, dois deles atacam o terceiro. O sangue e as vísceras do alien atacado corroem o chão, permitindo a fuga dos restantes. Gediman entra na cela dos aliens e, quando se baixa para inspecionar o buraco causado pelo ácido, uma garra segura-lhe o rosto e puxa-o.

No ginásio da Auriga, Call tenta justificar-se, explicando as atividades criminosas de Wren. Christie manda-a calar e a voz do computador Father ouve-se no momento em que a imagem passa para o anedótico General Perez, que acorda e coloca o boné.

O grupo da Betty resolve regressar à nave, levando Wren e o soldado sobrevivente para os conduzir até à saída. Perante este plano, Call pergunta sobre o que fazer com Vriess e Elgyn diz 'que se lixe Vriess', mostrando que a camaradagem não é um valor a ter em conta quando a sobrevivência está ameaçada.

Vriess aparece na sua cadeira, sozinho. Father anuncia que foram abertas sem autorização as jaulas três, cinco, sete, oito e dez, o que permite especular sobre a quantidade de aliens que se encontra à solta pela Auriga. Vriess vê o vulto de um alien no nível superior, prepara a arma embutida na sua cadeira de rodas e dispara sobre ele. 
No cais de embarque, Perez comanda as manobras de evacuação. Um dos alien entra numa nave de fuga e começa a matar os homens presos no seu interior. Perez atira uma granada que faz explodir a nave uns segundos depois, já no espaço. No momento em que faz continência pelos soldados mortos, Perez é atacado por um alien e, com espanto, retira um pedaço do seu próprio crânio, ilustrando os excessos de grotesco de que Jeunet foi acusado.

Os planos seguintes são do movimento simultâneo dos aliens contra a porta da cela de Ripley e desta contra a proteção do sistema de comando que lhe permite a fuga. Usa o ácido do seu sangue para destruir os circuitos e ativar a saída de emergência e foge. Father avisa que a evacuação foi incompleta e que a Auriga é considerada inabitável.

O grupo de tripulantes da Betty está em movimento para regressar à sua nave. Elgyn apanha uma arma que se encontra no chão de um dos túneis laterais e é atacado. Liderados por Hillard, o grupo encontra o corpo de Elgyn suspenso numa conduta. Quando se preparam para o puxar, surge um alien. Call olha para ele com fascínio e Johner puxa-a para fugirem. Tentam recuar, mas a porta está trancada. A criatura avança em direção ao grupo, parando quando ouve um ruído que vem do sítio onde está o corpo de Elgyn. Aproxima-se e do peito aberto de Elgyn emerge uma arma que dispara.

Ripley revela-se como a salvadora do grupo. Estranhamente, mudou de roupa. A roupa anterior fazia lembrar um colete de forças, mas agora Ripley está livre e vestida de cabedal, aproximando-se visualmente do alien ${ }^{9}$, embora não seja explicado ao espetador como e quando arranjou tempo para mudar de roupa.

Com a morte de Elgyn, Johner e Christie disputam a liderança do grupo. Call explica que Ripley não é humana e que se virará contra eles. Christie decide que, ainda assim, ela vai com eles. Quando se preparam para continuar o caminho até à Betty, Ripley arranca a língua do alien que matara e entrega-a a Call, dizendo-lhe que é um bom souvenir. A ironia dos diálogos

\footnotetext{
9 Segundo Gallardo e Smith (2004:177), a nova roupa serve também para estabelecer o estilo dominatrix das personagens femme fatale, como a Catwoman de Batman Returns (1992), que funcionam como uma afirmação "she is out, she is free and she is bad."
} 
curtos sublinha a diferença entre esta nova Ripley e a dos filmes anteriores, como se o ADN do alien lhe tivesse apurado também o sentido de humor.

Ripley alerta o grupo para o facto de a nave estar em movimento. Call confirma a sensação de Ripley, sugerindo pela primeira vez que ela própria poderá não ser inteiramente humana, uma vez que a nave tem um estabilizador que torna impercetível a deslocação. Wren confirma que o regresso à terra em piloto automático é o procedimento de emergência normal em caso de ataque. Johner diz que prefere ficar ali com os monstros, sugerindo que a Terra desse futuro não será um local aprazível. O planeta está a três horas de distância e Call sugere que façam explodir a Auriga.

O grupo avança. O peito de Ripley está visível e já não há vestígio de cicatriz. Johner pergunta-lhe o que fez no seu anterior encontro com os aliens. Ela sorri e responde-lhe que morreu. Tomadas de imagem em picado e contra-picado sublinham o facto de o perigo poder surgir de qualquer lado. Ripey pára em frente a uma porta que tem escrito 1-7. Há um grande plano dos olhos de Ripley captados através do vidro em que estão impressos os dígitos e, de seguida, um plano do braço de Ripley, onde está tatuado o número oito. A porta abre. Dentro de cilindros de contenção estão várias possibilidades de combinação Ripley/alien. Numa maca, ainda vivo, está um corpo disforme com a cara de Ripley e uma cicatriz no peito. Ripley usa o lança chamas, como usara em Aliens - O Reencontro Final, destruindo os contentores, que explodem com o calor, matando os outros clones. Pela primeira vez no filme, Ripley mostra-se vulnerável e chora enquanto se afasta do laboratório em chamas. Um plano da nave em movimento estabelece novamente a urgência da fuga e destruição dos aliens. No interior, o grupo passa pela divisão onde a mercadoria trazida pela Betty jaz, de peitos abertos. Deitado num canto, inexplicavelmente livre das amarras metálicas, está um humano. A personagem permite perceber que se tratava de colonos em sono criogénico, em viagem para o planeta Xarem. Ripley sente que ele está incubado e alerta o grupo. Discutem o que fazer com o colono. Christie sugere dar-lhe um tiro na nuca, mas Call e Hillard, as mulheres do grupo, consideram que terá de haver outra solução. Perante a insistência do colono em saber o que tem dentro de si, Ripley diz-lhe que tem um monstro no peito que dentro de algumas horas nascerá, 
rebentando-lhe as costelas. Purvis, o colono, pergunta-lhe quem é ela e Ripley responde, com um sorriso, que é a mãe do monstro.

Purvis segue com o grupo. Têm de descer por uma conduta, o que obriga Vriess a abandonar a cadeira. Christie carrega-o às costas. Um plano picado mostra o avanço do grupo, com a água a correr sobre eles fazendo lembrar a fornalha do filme anterior. Quando chegam ao fim do corredor, Wren explica que terão de atravessar vinte e sete metros debaixo de água para alcançarem o elevador do outro lado. Hillard é a última a mergulhar. É dela o primeiro plano debaixo de água e o último antes de perceberem que são seguidos por dois aliens. Johner dispara sobre eles. O primeiro desvia-se e o segundo é atingido. Hillard nada freneticamente, mas o alien sobrevivente aproxima-se. Agarra-lhe uma perna e puxa-a, deixando em seu lugar a imagem das bolhas do oxigénio libertado pelo seu grito.

Quando se preparam para emergir, Purvis e Call deparam-se com uma barreira, uma espécie de membrana orgânica, transparente, que bloqueia as três saídas, formando uma imagem de luz e sombra semelhante a uma caveira. Juntam-se para romper a membrana. Um plano revela que no exterior estão ovos. Quando emergem, um face bugger sai do ovo e envolve a cara de Ripley. Outros ovos abrem. Face huggers preparam-se para atacar os sobreviventes, que submergem para descobrir um alien adulto. Revelando a competência já estabelecida na cena do ginásio, Christie dispara sobre os ovos calculando o ricochete das balas. Os ovos rebentam. O alien que os persegue ruge, como se sofresse perda ou frustração. Ripley liberta-se do face hugger e desvia-se do ataque do alien. O grupo chega à superfície. Sobem pelas escadas para um andar superior e Wren tenta abrir uma porta. Pede a arma a Call para poder desativar o comando, e esta dá-lha sem hesitar. Wren dispara sobre ela e a jovem cai na água, de braços abertos, como Ripley mergulhara no metal no filme anterior. Vriess dispara sobre Wren e com uma das balas abre inadvertidamente o comando da porta. Wren escapa, como Burke em Aliens - O Reencontro Final, mandando o computador Father trancar a porta atrás de si. Da água emerge o alien que, num só movimento, chega à escada onde Christie e Vriess se encontram. Johner está estranhamente ausente desta sequência. Christie dispara, mas o alien desvia-se e lança um jato de ácido que lhe acerta na cara. Christie 
grita em agonia e solta um dos braços que o prende à escada e depois o outro, caindo. É Vriess, preso às suas costas, quem consegue salvá-los, agarrando-se à escada. A cena é trágica do ponto de vista visual e narrativo, mas é pouco credível que o alien, tão rápido e letal em todas as outras cenas, se limitasse a assistir à luta pela sobrevivência dos dois homens. O alien puxa a perna de Christie, obrigando Vriess a fazer mais força para os manter presos à escada. É apenas neste momento que Johner intervém, disparando e acertando na testa do alienígena que, apesar de morto, se mantém preso ao pé de Christie, constituindo um fardo adicional para Vriess. Grandes planos de Vriess mostram a dimensão do seu esforço, mas o peso é excessivo e solta uma das mãos. Todos os outros personagens estão ausentes. Ninguém oferece ajuda, obrigando Christie a sacrificar-se por ambos ao cortar as amarras que o prendem a Vriess. Esta cena ecoa a morte de Vasquez e Gorman em Aliens - O Reencontro Final, mas é menos consistente e eficaz uma vez que Christie não mostra nenhuma incapacidade ou dano além da queimadura do ácido no rosto, o que não o impediria de, uma vez liberto do peso do alien, voltar a emergir.

Um conjunto de planos estabelece a posição relativa dos elementos do grupo. Johner está com Distephano e Purvis junto à escada, Vriess sobe e Ripley está junto à porta, entretanto trancada por ordem de Wren. O alarme dispara, gerando tensão. O escuro é iluminado por fragmentos ritmados de luz, acompanhados do som de um alarme sonoro. As armas estão apontadas à porta, que abre revelando umas botas de estilo militar. A câmara sobe e, entre fumo, mostra Call. A primeira a olhá-la com espanto é Ripley. Depois todos os outros, à exceção de Distephano, vão mostrando surpresa. A rapariga apressa-os indicando o caminho.

Vriess expressa o seu contentamento e Distephano pergunta se ela tinha um colete vestido. Call responde afirmativamente, mas Ripley insiste que a viu ser atingida no peito. Abre-lhe o casaco e descobre um buraco de onde escorre um líquido branco. As unhas escuras de Ripley e o sangue branco de Call são duas singularidades cromáticas que estabelecem a estranheza e hibridez de ambas. Com alguma surpresa, Ripley pergunta-lhe se ela é um robô. E depois acrescenta que já o devia ter calculado, pois nenhum ser humano tem tanta humanidade. Johner, sorrindo, diz que pensava que 
os seres sintéticos eram lógicos, mas que ela é apenas psicótica. Vriess quer saber se ela é de segunda geração e Distephano pergunta-lhe se é um Auton, robôs desenhado por robôs que deveriam ter revitalizado a indústria sintética mas que acabaram por destruí-la porque não gostavam de obedecer a ordens, acabando por ser recolhidos pelo governo. Ripley passa a mão pelos ombros de Call, num gesto de carinho. Johner pergunta a Vriess se tem uma chave de fendas para mudar o óleo de Call, dando uma pequena cabeçada ao androide.

Ripley lembra que Wren pode usar o computador contra eles, mas que Call, enquanto ser sintético, lhe pode aceder. A cena seguinte decorre na capela, onde existe um dos acessos ao terminal. Call genuflete e benze-se ao entrar. Ripley, surpreendida, pergunta-lhe se está programada para fazer isso. No decurso do diálogo Ripley abre a Bíblia Sagrada, onde está o terminal que vai permitir Call ligar-se ao Father. Insere o cabo no braço, como uma seringa hipodérmica, e descobre que não vai conseguir fazer explodir a nave porque gastaram demasiada energia. Ripley decide então fazê-la colidir com a Terra. Call ajusta os níveis para que a nave se despenhe quando atingir a atmosfera, calculando que restam quarenta e três minutos até ao impacto. Ripley diz-lhe para arranjar caminho livre até à Betty e para a pôr em funcionamento. As imagens seguintes são de portas a abrir, entre fumo. Os brilhos cromados dos laboratórios no início do filme dão lugar ao metal ferroso, criando uma assimetria cromática e de estilo que, ao contrário do que acontece na Nostromo, não é geograficamente situada nem simboliza qualquer hierarquia ou distinção social.

$\mathrm{Na}$ Betty, luzes acendem e computadores iniciam-se. Call deteta uma anomalia. Wren está a chegar à Betty. Call desliga a energia do setor onde ele se encontra. Wren pede a Father para detetar a fonte da perda da energia. Tal como Ripley fizera com Mother, também Wren grita por Father quando este não responde ao seu pedido. Call responde em seu lugar, comunicando-lhe que Father está morto e indicando aos aliens o local em que Wren se encontra.

$\mathrm{Na}$ capela as mulheres continuam a conversa. Trocam receitas de como não ser humano e sobreviver. A androide pergunta a Ripley como consegue viver e aguentar ser o que é. Ripley responde que não tem escolha. Call 
baixa os olhos e diz que pelo menos uma parte de Ripley é humana, enquanto ela é simplesmente repugnante. Ripley pergunta-lhe o que foi fazer à nave. Call responde que foi lá para a matar. Explica que, antes da recolha dos Auton, teve acesso aos computadores centrais do governo e ficou a saber de todos os planos. Ripley pergunta-lhe porque se importa tanto e Call responde que foi programada assim.

Distephano chama-as e o grupo volta a dirigir-se para a Betty, com Purvis e Distephano a carregar a cadeira de Vriess. Call e Purvis pisam o visco dos aliens. Ripley cheira-o e diz que estão perto do ninho. Johner ameaça matar Call se ela tiver feito alguma coisa que impeça a sua sobrevivência. Quando avança para o androide, Ripley segura-o pelo pescoço e puxa-lhe a língua, perguntando a Call se quer outra lembrança. Todos correm em direção às docas. Ripley segue em último e abranda, ajoelhando-se no gradeamento inferior. Explica a Call que consegue ouvir os alien e que a rainha está com dores. Quando se levanta e prepara para seguir, o gradeamento é puxado e Ripley cai.

O corpo de Ripley afunda-se e funde-se numa massa de formas e sombras. Purvis e Call assistem. Purvis diz que o melhor a fazerem é rezar para que Ripley tenha uma morte rápida. O rosto transpirado de Ripley e o seu fato de cabedal permitem uma continuidade cromática e estética entre todos os corpos. Os movimentos são lentos e sensuais, numa espécie de bailado ou coreografia, num abraço entre as duas espécies, entre as duas naturezas de Ripley.

Um plano de exterior mostra a Auriga no seu curso pelo espaço, em direção ao planeta Terra, onde se despenhará. Dado o volume da nave, pode imaginar-se o tipo de estragos que provocará, embora isso não seja tido em conta na narrativa. A Terra aparece no ecrã, próxima, como um alvo a que a Auriga aponta. O grupo de sobreviventes chega à Betty. Quando Johner, a pedido de Call, se prepara para pôr Purvis em sono criogénico, um tiro é disparado sobre o colono. Wren entra na nave, usando Call como escudo e como refém. Ameaça pôr uma bala no seu cérebro e, apesar de todos saberem que ela é sintética, os homens não atacam Wren e entregam as armas. Wren pretende fazer Call ligar-se à Auriga e cumprir o plano inicial de levar a nave até casa, cumprindo os procedimentos 
normais de emergência. Uma imagem de Purvis mostra que o alien está prestes a irromper do seu peito. O colono levanta-se e dirige-se para onde o grupo está. Wren afasta Call e dispara sobre Purvis, que continua a avançar apesar dos repetidos tiros que o atingem. Esmurra Wren e coloca a cabeça do cientista ao nível do seu peito. O grito de Purvis é acompanhado de uma imagem do interior da sua boca, descendo pela traqueia até ao embrião que se agita. A imagem seguinte é a do alien a irromper pela cabeça de Wren, depois de ter atravessado o peito de Purvis. Johner e Distephano disparam sobre Purvis, Wren e o monstro, os três fundidos numa mesma massa física.

De volta a Ripley e ao castanho orgânico da cave onde habitam os monstros, uma voz fala. É Gediman, de quem apenas a cabeça mantém cor e forma humanas. Explica o ciclo de gestação da rainha. A câmara afasta-se e mostra um plano de conjunto, em que se veem várias cabeças, presas como Gediman, numa massa orgânica envolvente. No chão, Ripley está deitada. Gediman continua a explicar que a rainha tem agora um sistema reprodutivo humano, dádiva resultante da mistura genética com Ripley, e que está a dar à luz. Agora é perfeita, diz, repetindo as palavras que usara para caracterizar Ripley, clone número oito, enquanto a imagem mostra a rainha deitada, de ventre proeminente, a sofrer dores de parto. Do seu ventre sai um ser envolto em muco. Não se assemelha ao alien. Tem uma morfologia mais próxima do ser humano e o tom metálico é substituído por um tom rosado. Gediman, que assiste a tudo a partir da sua prisão orgânica, chama-lhe maravilhosa borboleta.

O recém-nascido aproxima-se da mãe que geme carinhosamente. O novo ser, com cavidades oculares, dentes menos proeminentes e uma espécie de nariz, cheira a mãe. Afasta-se um instante e ataca-a, matando-a. Um grande plano mostra que dentro das cavidades oculares estão olhos, negros e brilhantes. Um plano de Ripley estabelece a continuidade do olhar do monstro. Ripley encosta-se à parede, assustada, e evita olhar para o novo ser que se aproxima e a cheira, como fizera com a rainha. Uma língua sai da sua boca para lamber a face de Ripley. Gediman chama-lhe lindo bebé e atrai a atenção do alien, que se aproxima do cientista emitindo sons quase carinhosos. Inesperadamente, morde a sua cabeça, matando-o. Ripley aproveita para 
fugir. No cais, Betty prepara-se para abandonar a Auriga. Ripley corre, mais uma vez entre fumo e luzes vermelhas de emergência. Vriess e Call tentam pilotar a saída da nave. As imagens da preparação do voo são alternadas com a corrida de Ripley pelos corredores da Auriga. A nave está preparada. Call vê Ripley pelo ecrã do interior da nave. Abre as portas e Ripley faz um salto impressionante, aterrando a bordo da Betty. Os outros membros do grupo ficam satisfeitos, incluindo Johner, que lhe pergunta se sabe pilotar uma nave. Ripley responde que a nave é mais velha do que ela, e prepara-se para assumir os comandos. Vriess deteta que ainda têm uma escotilha aberta. Johner prepara-se para ir verificar, mas Call diz que o ela própria o fará. O computador informa que se estão a aproximar da atmosfera da Terra e que a partida da Betty se fará em quarenta e seis segundos. Call tenta fechar o pedaço de escotilha ainda aberto. Ripley chama Call, apressando-a para partirem. Mas o alien surge por detrás da androide, assustando-a. É ele quem puxa a escotilha, fechando-a e permitindo a partida da nave. A montagem alterna imagens da pilotagem da nave com imagens da luta de Call, ambas com a trepidação da descolagem. Do exterior, vê-se a pequena Betty a abandonar a imensa Auriga.

Call esconde-se, como Newt, num pequeno espaço por onde o alien não consegue passar. Sem conseguir agarrá-la, o ser faz a sua expressão mais humana, de olhos suplicantes, emitindo sons de dor. Call olha surpreendida e hesitante. Distephano entra para ver o que se passa. Call grita, mas é demasiado tarde. O ser, com um único movimento, esmaga a cabeça do soldado. Call rasteja para fora do seu esconderijo. Na cabine de pilotagem, Ripley e Vriess pilotam a nave, enquanto Johner tenta reparar uma peça, queixando-se que a sua profissão não é ser mecânico, mas basicamente consiste em fazer mal às pessoas. Vriess chama Call, mas esta não responde. Ripley percebe então o que poderá estar a passar-se e levanta-se da cadeira de piloto.

No cais o alien acaricia Call. Depois, descobrindo a sua vulnerabilidade, introduz os dedos ou garras no orifício provocado pela bala de Wren. Call grita. Ripley chega e manda-o pousar Call. É uma cena que faz lembrar a atitude protetora em relação a Newt no confronto final do segundo filme. O ser obedece e ouve-se um som semelhante ao de um cão que pretende 
agradar ao dono. Ripley aproxima-se, juntando o rosto dele ao seu. Há um longo momento em que monstro e clone se acariciam sensualmente. Ripley percebe que tem sangue na mão e atira-o para a escotilha. O ácido começa a corroer o vidro. O ser é alertado pelo ruído e olha nessa direção. Um buraco forma-se. O vácuo começa a sugar o ar no interior da nave. Ripley e Call seguram-se e o alien é sugado, tapando o buraco com o seu corpo. Do exterior da nave vê-se a lenta saída de órgãos e vísceras. Ripley observa, chorando. Pede desculpa ao seu novo filho que agoniza, sendo completamente sugado para o exterior da nave. Call estende o braço a Ripley e as duas mulheres seguram-se.

Este não era o final estabelecido numa das versões anteriores do guião, em que Ripley e Call apenas confrontavam o alien depois de terem aterrado no planeta Terra, esventrando-o com as máquinas em que Call e Vriess trabalham numa das cenas iniciais da Betty.

Uma sucessão de planos de aliens a vaguear pelos corredores vazios da Auriga, acompanhados pela voz de Father a anunciar a contagem decrescente para o impacto, seguidos de uma explosão, estabelecem o fim da nave e o extermínio da espécie. Na Betty, as mulheres continuam abraçadas. Vriess e Johner atravessam a atmosfera. Através das janelas da nave veem-se nuvens e o sol. Johner beija Vriess e Ripley diz a Call que ela conseguiu o seu objetivo: salvou a Terra.

A imagem é difusa, com o planeta Terra refletido no vidro por onde as mulheres o observam, em sobreposição com as suas caras. Call diz que nunca esperou que a Terra fosse linda, mostrando que também não a conhecia. Pergunta a Ripley o que acontecerá a seguir. Ripley, serena, responde que também não sabe. Ela própria é uma estranha ali.

Os custos de Alien: O Regresso ultrapassaram os oitenta milhões de dólares. Nas bilheteiras dos Estados Unidos só conseguiu chegar aos quarenta e seis milhões em receitas, ficando atrás de filmes como Titanic e O Jogo, realizados respetivamente por James Cameron e David Fincher, e de outros filmes classificados como ficção científica, como MIB (Barry Sonnenfeld), Parque Jurássico (Steven Spielberg), Batman e Robin (Joel Schumacher), 
Contacto (Robert Zemeckis), O Cume de Dante (Roger Donaldson) e O Quinto Elemento (Luc Bresson), todos de $1997^{10}$.

Pela primeira vez na história da saga, a Fox tomou a decisão de não enviar videocassete aos membros da Academia e, pela primeira vez também, um filme Alien não foi nomeado para o Óscar de melhores efeitos visuais. No entanto, o filme recuperou receitas nas bilheteiras do estrangeiro, chegando aos cem mil dólares, sem que isso tenha sido o suficiente para o estúdio investir no quinto filme durante a década seguinte, tendo preferido apostar em filmes como Alien vs Predador (Paul Anderson, 2004) e Alien vs Predador - Requiem (Colin e Greg Strause, 2007), ambos a conseguirem ultrapassar confortavelmente os cem milhões de dólares de receitas de bilheteira em todo o mundo.

À imagem dos filmes anteriores, a visão proposta por este quarto filme é distópica. A United Systems Military substitui a corporação capitalista e assume-se como uma nova forma de poder global, resultante da aliança entre a organização militar e a ciência, o que sugere a existência de um estado de guerra permanente. Continua a existir crime, vigilância e secretismo, e o poder mantém o desprezo pela vida humana.

A tecnologia, representada por Call, está redimida das versões negativas anteriores, mostrando-se capaz de mais humanidade do que os humanos. O próprio computador Father apresenta-se como mero instrumento, sem bondade ou maldade intrínseca, acabando por ser facilmente desativado por Call. Por oposição, os processos científicos são apresentados como agentes de destruição humana, sendo os cientistas retratados como caricaturas grotescas.

A alteridade é a categoria central em Alien - O Regresso, não tanto na exploração da figura do alien, mas nas múltiplas possibilidades de hibridação. Tempo e espaço servem apenas para estabelecer o contexto em que decorre a ação e é a ciência, mais do que a tecnologia, que assume protagonismo, essencialmente por permitir a replicação e a fusão do humano e do não humano. O alien continua a ser retratado como entidade malévola, mas apresenta neste filme características morfológicas, fisiológicas e comportamentais

\footnotetext{
10 Dados constantes da página BoxOffice Report (www.boxofficereport.com).
} 
humanas, enquanto Ripley, clone número oito, se apresenta como a versão humana do alien, obrigando a um olhar mais atento sobre a questão da hibridez enquanto base de construção identitária.

78

Apesar de não terem sido sucessos de bilheteira estrondosos, os quatro filmes tornaram-se objetos de culto. São ilustrativos da história do cinema de ficção científica recente e refletem, metaforicamente, as preocupações dominantes em relação à ciência e tecnologia, à identidade e alteridade, ao tempo e espaço, e até mesmo ao lugar da mulher na sociedade, podendo por isso proceder-se à sua análise nessas várias categorias. 
HUMANOS E NÃO HUMANOS NOS FILMES ALIEN

I'm the monster's mother.

Ellen Ripley

\section{NÃO HUMANOS}

Respondendo às exigências de mercado, à especificidade comunicativa, ao estado de desenvolvimento do medium, às tendências genológicas, à visão dos autores e às ansiedades do contexto, os filmes Alien refletem, como a filmografia de ficção científica mais geral, as ansiedades relativas à tecnologia, ao futuro, ao domínio capitalista, ao desenvolvimento científico e às fronteiras entre humano e não humano, conhecido e estranho.

A figura que representa primariamente o não humano, a alteridade absoluta, é o alien, um ser complexo, morfologicamente rico, com múltiplas fases de desenvolvimento e uma estrutura social centralizada. As suas características biológicas, comportamentais e sociais estabelecem-no como radicalmente outro, como o contrário do humano, sem fragilidades, emoções, centro identitário ou propósitos claros. O alien é um ser destrutivo, violento, que permite múltiplas formas de malevolência: é parasita, violador, invasor e inimigo. No entanto, para Bukatman (1993:266) a espécie é, na realidade, muito impura: é humanoide, mas não humano; é simultaneamente feminino e masculino; é encontrada num espaço semelhante a uma vagina e um útero, mas ataca falicamente as mulheres da tripulação; nasce de ovos, mas continuamente se dá à luz através dos portadores que insemina. 
O primeiro filme, estando colocado na fronteira entre a ficção científica e o terror, explora o potencial do alien para despertar medo no espetador.

O alien representa o monstruoso, a violência, o inesperado. Mas aquilo que torna o filme num fenómeno de culto é a capacidade de tornar essa diferença credível, fazendo do alien um dos monstros mais assustadores da história do cinema. De acordo com Greenberg (id.) o sucesso da criatura deve-se à conjugação de um conjunto de características improváveis, entre as quais ser misteriosa, dinâmica, implacável e bela. A estratégia de Scott consiste em mostrar o alien de modo breve e ambíguo, em imagens parciais que duram poucos segundos, obrigando o espetador a construir uma perceção a partir de fragmentos visuais, completada com a imaginação dos seus próprios medos.

A mutabilidade do ser é também uma estratégia que permite alimentar a surpresa contínua. As várias e radicais mudanças ao longo do ciclo de vida fornecem um potencial de transformação e adaptação rápido, alimentando o suspense e o medo. Por outro lado, a informação sobre a espécie é escassa. Não se sabe a sua origem, a razão da sua estadia no planeta nem o modo como a vida foi suportada na sua fase de ovo. Mais uma vez, cabe ao espetador preencher os vazios informativos, trazendo a jogo a sua imaginação, os seus conhecimentos e as capacidades extrapolativas.

A implacabilidade é outra característica apontada por Greenberg. Ao contrário dos monstros inspiradores de simpatia por representarem o não humano perseguido, o alien apresenta-se como um predador implacável, sem empatia nem remorsos, deixando mais uma vez à imaginação um espaço de construção de terror, uma vez que as mortes nunca são visualmente representadas.

Mas o sucesso do alien deve-se também à sua dimensão estética. Nas suas múltiplas formas, como face hugger, chestburster ou alien adulto, concilia malevolência com elegância e beleza. Desenhado por H. R. Giger, o alien combina elementos ósseos com estruturas mecânicas e metálicas, conjugados de modo artístico, fazendo lembrar a iconografia das figuras demoníacas.

A capacidade de impressionar e surpreender dilui-se nos filmes seguintes. O tratamento militar do segundo e a religiosidade do terceiro retiram alguma da carga metafórica e transformam a criatura simplesmente em 
inimigo e em demónio, fazendo-o perder alguma da beleza e sensualidade existente no oitavo passageiro. De todos, o terceiro filme é o que mostra um alien menos assustador. Depois do encontro da espécie com os marines e da rainha com Ripley, não é credível assumir que o espetador se assuste com um único organismo, ainda que seja no espaço fechado de uma prisão, rodeado de criminosos violentos.

O quarto filme é inovador em relação ao alien. Pela primeira vez é explicitamente considerado como um ser inteligente, mais próximo do humano, e não uma besta divinizada como no terceiro filme ou um exército organizado como em Aliens - O Reencontro Final. Essa inteligência resulta da sua hibridação com o humano e torna-o mais perigoso mas simultaneamente mais inspirador de simpatia, como acontece com a rainha ou o alien nascido do seu ventre, obrigando a novas articulações e novos posicionamentos entre os conceitos de alteridade e identidade, como veremos adiante.

Mas o não humano é também representado pela tecnologia, nomeadamente nas figuras de Ash, Bishop e Call, os androides, e Mother e Father, os computadores da Nostromo e da Auriga.

No primeiro filme, Ash e Mother são agentes que se opõem ao humano de modo irreconciliável, transformando-se em inimigos. Sinal das ansiedades epocais, o computador desempenha um papel central no primeiro filme. É Mother que decide alterar o rumo para responder ao sinal do planeta LV426 e se vinga de Ripley ao detonar o mecanismo de autodestruição da nave. A ideia de um ambiente se tornar vivo e se virar contra os protagonistas é recorrente nos filmes de terror, mas a originalidade de Alien, à semelhança de 2001 - Odisseia no Espaço, é fazê-lo através da tecnologia. No entanto, nos filmes seguintes o computador deixa de ser protagonista, e mesmo o Father de Alien - O Regresso tem um valor intertextual, sendo facilmente desativado por Call.

Já o androide é personagem central nos quatro filmes. Ash é um androide com intenções sinistras, cuja natureza sintética só é revelada quase no final. A sua tarefa de cientista ilustra a aliança entre a tecnologia e a ciência e reflete pessimismo em relação à frieza e amoralismo da racionalidade tecnocientífica. Ash é o duplo maquínico do alien, o outro tecnológico que ameaça igualmente a espécie e os valores humanos e que constitui para 
Ripley um perigo tão concreto como o próprio alien. No filme seguinte a tecnologia é redimida. É ela que permite o resgate dos sobreviventes e a destruição da espécie alienígena. Tanto as naves como Bishop, o novo androide, se revelam fiáveis e ao serviço dos humanos.

Em Alien $^{3}$ Bishop volta a aparecer, identificando-se como o seu criador humano. No entanto, o líquido branco que escorre da sua cabeça quando é agredido denuncia a sua essência sintética e marca o tom tecnofóbico. A tecnologia, quer na figura de Bishop quer na permanente vigilância da Companhia, constitui-se mais uma vez como inimigo, tão frio e implacável com o alien.

Como nota Kaveney (2005:195), Call é a terceira androide da série, numa sequência alfabética A, B e C: Ash, Bishop e Call. Esta sequência significa também um apuramento moral. Call partilha com Ripley a capacidade de morrer e renascer, e, tal como ela, morre com os braços abertos, em forma de crucificação, num sacrifício pela humanidade.

A relação entre a tecnologia e o cristianismo pode encontrar-se também na designação de Father, atribuída ao computador da nave Auriga, e ao facto de apenas se conseguir aceder ao computador central a partir da capela, onde Call genuflete e faz o sinal da cruz. É em Call, mais do que em qualquer outra personagem, que reside a esperança de perpetuação de uma qualquer noção de ética, o que traduz um otimismo em relação à tecnologia do futuro e identificação da essência humana com a figura do ciborgue.

As naves são também entidades não humanas na medida em que são construções mecânicas, espaços tecnológicos que se podem considerar também um corpo, uma entidade viva.

Bukatman (1993:266) considera que a separação entre a tecnologia racional e a biologia viscosa é quase um princípio estruturante da ficção científica. No entanto em Alien isto não acontece. Há transgressão entre biologia e tecnologia através de fluidos, distinguindo-se da restante ficção científica: o vapor e a água da nave, o jato de sangue de Kane, o líquido leitoso de Ash, o sangue corrosivo do alien, o visco da sua boca. A originalidade em Alien é a inclusão do corpo nos espaços racionais e assexuados da ficção científica, numa fusão entre orgânico e não orgânico. Nas imagens iniciais do primeiro filme da série, a Nostromo parece um armazém 
abandonado a flutuar no espaço, com a imensa superfície da nave envolta em sombras, vagamente ameaçadora, capaz de provocar no espetador uma vaga inquietação. O seu interior também é assustador, principalmente quando se desce para os pisos inferiores. Mas é a nave encontrada no planeta LV426 que melhor combina a tecnologia com o orgânico, sem que seja explicada a sua origem, função ou destino. O próprio alien fossilizado se funde com a nave, sendo difícil ao espetador determinar os limites do corpo e da tecnologia, assumindo a dissolução de fronteiras entre ambos na construção das próprias identidades.

Esta fusão entre o orgânico e a tecnologia na construção do espaço envolvente não acontece de forma tão clara nos outros filmes da série. A Sulaco é um cenário neutro e a estação terraformada de LV426 também. A malevolência que neles habita não é intrínseca mas resulta da ameaça alienígena. A Auriga representa também um microcosmos onde se replica a diversidade humana, essa sim portadora de ameaças várias. Apenas a prisão de Fiorina 161, um espaço de violência, fé e demência, replica a inquietação provocada pela Nostromo, embora o excesso de simbolismo e ausência de tecnologia reduzam o seu potencial enquanto dispositivo narrativo autónomo.

\section{HUMANOS E HÍBRIDOS}

A noção de identidade humana é central para a série, mas não é unidimensional nem pacífica. No primeiro filme os membros da tripulação não têm história nem uma dimensão psicológica redonda. De acordo com Bukatman (id.:263), são simulacros funcionais e o próprio alien é uma criatura de transformação contínua, ilustrando deste modo a condição pós-moderna. Esta situação não se altera profundamente nos dois filmes que se seguem, embora a abordagem de David Fincher seja mais centrada nas personagens humanas do que no ser alienígena. Mas é no quarto filme que as fronteiras e hibridações da condição humana são explicitamente abordadas, através da proposta de múltiplas formas de combinação entre humano e não humano. Em Alien - O Regresso poucos são os personagens unidimensionais, e os que o são, como Gediman e o General Perez, funcionam como estereótipos 
de cientista louco e militar fanático. Neste filme, a oposição entre Ripley e o alien, os dois personagens centrais da série, representantes do humano e do não humano, deixa de ser clara e demarcada. O outro passa efetivamente a ser parte do eu e o eu passa a ser parte do outro. Há uma humanização do monstro e uma monstrização do humano. Como referem Gallardo e Smith (2004), a monstruosidade passa a ser o modelo de identidade.

A identidade de Ripley é ambígua desde o início do filme. Embora se pareça com a Ripley dos filmes anteriores, o seu estatuto de híbrido, de não humano, é constantemente sublinhado. O seu sangue é ácido, as unhas são escuras e tem força sobre-humana. As tomadas de imagem são feitas de modo a sublinhar a sua altura e a roupa justa assenta como uma segunda pele, semelhante à do alien.

Paralelamente, a espécie opositora é humanizada. Os alien revelam-se mais inteligentes, mais racionais, capazes de planear uma estratégia de fuga. A rainha ganha um sistema reprodutor semelhante ao humano, dando à luz um ser com crânio e pele. Este híbrido é também a corporização da duplicidade: mata a sua mãe biológica e Gediman, um dos seus pais humanos, escolhendo para mãe a humana Ripley que, ambiguamente, o seduz, o mata e sofre a sua perda.

Entre os tripulantes da nave Betty podemos encontrar também duplicidades e hibridações. Johner, que na primeira cena em que aparece imita um macaco, é uma personagem próxima da animalidade. Vriess, paraplégico, depende da cadeira de rodas para locomoção e sobrevivência, assumindo uma meia natureza mecânica, sublinhada pela paixão secreta pela androide Call, que, embora sintética, é quem se revela mais humana.

De acordo com Kaveney (2005:203), o único personagem que não se mostra meramente grotesco e não manifesta qualquer ambiguidade é Wren, embora a sua falta de humanidade seja, ela própria, uma forma de monstruosidade. Por outro lado, os únicos híbridos explícitos, os sete clones anteriores a Ripley, são inspiradores de simpatia, mas grotescos, porque a combinação de componentes humanos e alienígenas não permite uma separação clara nem uma ocultação.

A ambiguidade identitária também é moral: Call é tão ética na sua obsessão para defender a humanidade que se torna terrorista. Os tripulantes 
da Betty, assumidamente desonestos e responsáveis por trazerem os colonos para bordo da nave, são capazes de mostrar alguma camaradagem e empatia, e até o monstro na sua forma final provoca em Ripley um sentimento de perda.

Os quatro personagens que sobrevivem ao encontro com os aliens e regressam à terra são simultaneamente estrangeiros e híbridos, fundindo o melhor da humanidade com a alteridade, a animalidade e a tecnologia. Ripley é um híbrido humano/alien, Call é um androide, uma fusão máquina/humano, Vriess é um ciborgue, um paraplégico cuja cadeira de rodas funciona como extensão protésica potenciadora das capacidades humanas, e Johner, o único humano que não resulta de criação ou transformação científica ou tecnológica, é um ser cujo tamanho, comportamento e contornos faciais, remete para a relação humano/animal, fazendo lembrar os mutantes de A Ilha do Dr. Moreau.

Os sobreviventes do quarto filme não são os mais bonitos, nem os mais simpáticos nem essenciais à missão. A leitura possível é a de que, como defende Haraway (1991), o ciborgue, enquanto espaço de dissolução de categorias, se constitui como a forma de resistência e modelo identitário que melhor serve a contemporaneidade, permitindo a construção de identidades dinâmicas onde se cruzam o eu e o outro.

Analisando a questão da alteridade como desvio à noção de self ocidental masculino e caucasiano, a tetralogia pode também ser lida como uma narrativa de afirmação do outro enquanto feminino. No entanto, apesar de Helen Ripley ser a primeira heroína de ação, toda a série é ambígua no tratamento que é dado às representações de género, originando, por isso, interpretações contraditórias.

Como foi anteriormente referido, a escolha de Helen Ripley como sobrevivente da Nostromo pode dever-se a uma ancoragem aos filmes de terror. Ripley é, nessa perspetiva, uma final girl, a sobrevivente inesperada do confronto com o monstro, que se mostra mais esperta e com mais recursos do que as outras mulheres, em relação às quais é esperado que os homens assumam um papel protetor. A final girl inspira simultaneamente medo e excitação e, por isso, foi um dispositivo recorrente nos filmes de terror a 
partir da década de 1970. Mas, mesmo sendo a sobrevivente final, Ripley é uma mulher forte, determinada e, durante quase todo o filme, assexuada. É Lambert quem assume a fragilidade e desamparo correspondentes ao estereótipo feminino, enquanto Ripley assume a liderança do grupo, o que provavelmente terá contribuído para a construção e manutenção de Ripley como heroína de ação.

Por outro lado, o filme assume uma imagética misógina. Os espaços, principalmente a sala de controlo do computador Mother e a nave que está em LV426, assemelham-se ao organismo feminino, traduzindo ansiedade sexual num filme em que a personagem principal é uma mulher forte e competente. O corpo feminino, nomeadamente o sistema reprodutor, representam o perigo, o desconhecido, e contêm a alteridade, a diferença e a morte.

A identidade de género do monstro também é ambígua. Como refere Roberts (2000), no primeiro filme o alien é um macho agressivo que ataca e mata, penetra as vítimas com um falo monstruoso, um segundo conjunto de dentes que sai da sua boca. Este macho também engravida algumas das vítimas, independentemente de serem homens ou mulheres, com um feto mortal.

Mas à medida que a série progride esta identificação de género torna-se problemática. O alien acaba por se transformar numa versão mais violenta da mulher, permitindo a identificação da rainha com o monstruoso feminino e as restantes fêmeas com valores positivos. No entanto, Roz Kaveney (id.:151) argumenta que Newt e a rainha podem ambas ser entendidas como duplos, sombras de Ripley. Tal como Ripley, Newt perdeu todas as pessoas que conhecia e teve uma experiência de terror que a tornou possuidora de um conhecimento que os outros não detêm. A rainha é um monstro, mas com o qual Ripley foi capaz de comunicar e que, tal como Ripley, age movida pelo instinto de proteger e vingar as suas crias. A própria Vasquez pode considerar-se mais um duplo de Ripley, sendo no entanto a única fêmea adulta cuja motivação para lutar depende apenas da sua própria competência como lutadora e do respeito dos seus camaradas, e não de um instinto protetor maternal.

A importância do feminino é sublinhada pelo conflito final entre Ripley e a rainha. Hicks está inconsciente e Bishop, cuja natureza também é dupla, 
é desmembrado, deixando para as fêmeas o confronto entre o bem e o mal, o humano e o não humano.

Para Roberts (2000), a identificação do alien com o feminino é mais clara no terceiro filme, patente na frase promocional the bitch is back. No entanto essa identificação não parece óbvia, uma vez que o alien do filme possui uma violência facilmente identificável com a dos prisioneiros de duplo cromossoma Y e a rainha passa todo o filme em gestação no peito de Ripley para irromper apenas nos segundos que antecedem a sua morte.

No terceiro filme, além de se associar o duplo cromossoma Y, uma espécie de hipermasculinidade, à violência, Kaveney (2005) considera que Ripley é sujeita a um conjunto de indignidades, desde a quase violação a ter de rapar o cabelo devido aos piolhos. O mesmo autor considera que a tendência para desvalorizar a autonomia das personagens femininas está presente em quase todos os filmes de Fincher, incluindo The Panic Room, que, apesar de tratar da resistência de Meg (Jodie Foster) acaba por se centrar na redenção do personagem interpretado por Forest Witaker. Como o autor resume (id.:183):

"Onde Cameron se mostra obcecado com um modelo particular de poder feminino, que se pode argumentar ser romantizado ao ponto do fetichismo, Fincher está determinado em ser 'realista' até um limite que implica uma misoginia livremente expressa neste filme."

O autor acrescenta que, apesar de os filmes anteriores terem sido criticados pelos fluidos corporais e formas quase genitais, vistas como monstruosas, é no Alien $^{3}$ que a sexualidade é, ela própria, tomada como aberrante, quer pela violação iminente de Ripley, quer pelo facto de esta ter mantido relações sexuais com Clemens.

No quarto filme, a híbrida Ripley revela uma natureza sexualmente predadora, fazendo oscilar a sua tensão sexual entre o pirata Johner, a androide Call e o próprio alien. Mas o filme volta a abordar a maternidade, desta vez de uma forma mais complexa do que nos filmes anteriores. Já não se trata apenas do cumprimento da função protetora em relação às crias, mas do discurso da reprodução associado aos desenvolvimentos científicos. 
Patricia Linton ${ }^{11}$ reflete sobre o discurso de hibridação patente no Alien - O Regresso, considerando que o filme posiciona as duas mulheres como alienígenas. Mas, apesar disso, a maternidade é apresentada como melhor do que a paternidade. O pai criador são os cientistas, frios e disciplinadores, apresentados eles próprios como monstruosos e desumanos.

A cultura da nave é claramente patriarcal, o que está patente na escolha do nome Father para o computador central, um pai que Call mata ao longo da narrativa, e no apagamento do nome da cientista a bordo. Mas, tal como nos filmes anteriores, as personagens principais são mulheres: Ripley, Call e a rainha alien, três híbridas, como se a mensagem do filme fosse a de que a sobrevivência no feminino obriga a concessão, contaminação, adaptação. No sentido mais geral, as três fêmeas são tomadas como mães, como protetoras, mesmo a própria androide Call, programada para proteger os humanos. Apesar de Ripley ter morrido no filme anterior para evitar ser a mãe do monstro, neste filme é assumida como mãe da rainha, a terceira fêmea híbrida, que ganha de Ripley um sistema reprodutivo humano e dá à luz um ser que se parece com um dos clones do laboratório. O novo alien escolhe Ripley como mãe, matando os progenitores mais naturais: a rainha e Gediman. Segue Ripley até à Betty, disposto a partir com ela. Ripley, por seu lado, escolhe proteger Call, e, como sublinha Linton (id.), a morte do alien a ser sugado para o espaço parece quase literalmente um aborto.

A mensagem dos filmes, apesar de diferenciada e ambígua, pode entender-se como um discurso de sobrevivência, adaptabilidade e resistência do feminino. Os quatro filmes mostram que mulheres são mais aptas para sobreviver e que o fazem protegendo os mais fracos e defendendo a humanidade, sublinhando o seu papel maternal de cuidadora como característica distintiva em relação aos homens.

O último diálogo da tetralogia é entre Call e Ripley. Call pergunta o que vai acontecer e Ripley responde que não sabe, que ela própria é uma estranha, um alien, uma ameaça. Linton (ibid.) lembra o paralelo entre as duas

11 Aliens, (M)Others, Cyborgs: The Emerging Ideology of Hybridity, in Cartmell et al., 1999: $172-186$. 
mulheres: ambas não naturais, construídas, ambas sozinhas no sentido de não terem companhia, raça, cultura, espécie, ou qualquer forma de pertença.

\section{DISTOPIAS}

Os filmes Alien são filmes de futuro, que se vai dilatando de narrativa para narrativa recorrendo aos dispositivos de base científica ou tecnológica, como o hipersono e a clonagem.

As visões propostas são, todas elas, distópicas. Em nenhum deles a ação se passa diretamente no planeta Terra, embora esta esteja presente enquanto colonizadora no segundo e terceiro filmes e enquanto destino no primeiro e no quarto, sendo lá que termina a tetralogia. De qualquer modo, essencialmente pelas palavras de Johner, pode deduzir-se que a Terra não é um sítio onde a existência seja agradável, o que postula um futuro pior do que o presente.

Nos quatro filmes o grande inimigo, maior do que a ameaça direta e imediata que os aliens constituem, é a Companhia, símbolo dos valores mais negativos da humanidade, que não hesita em sacrificar a vida humana a troco de lucro. Como refere Harvey Greenberg (id.:99) a missão real da Nostromo e o modo desapaixonado como é levada a cabo ilustra a exploração desenvolvida a partir dos excessos do capitalismo terrestre, como, poderíamos acrescentar, o representa LV426, o complexo Fury 161 ou a própria Auriga.

No primeiro filme os interesses económicos aliam-se à tecnologia, constituindo-se Ash e Mother como executantes das suas diretivas denotando alguma malevolência que se traduz, não numa mera incapacidade de sentir, mas na incapacidade de sentir empaticamente. Greenberg (ibid.) considera que a família do Nostromo é assim ameaçada por três monstruosidades: o alien, Ash e a Companhia. o perigo mais imediato é o alien, mas é-o apenas do ponto de vista da vítima. Objetivamente não há nada de intrinsecamente mau na sua natureza uma vez que alimentar-se e procriar são razões naturais, imperativos biológicos que se impõem a qualquer espécie. Ash é o segundo monstro, introduzido pela Companhia para conseguir os seus propósitos. No entanto também não se pode considerar 
autonomamente mau porque é um ser pré-programado, que vê na pureza do alien um ideal robótico. A verdadeira monstruosidade moral é a Companhia, que se alimenta dos humanos, indiferente à sua sorte, e que procura alianças para prosseguir os seus interesses.

No segundo filme a aliança é estabelecida entre a Companhia e os militares, mas é Burke quem se assume como seu representante e como agente ativo do desejo de recolha, preservação e transporte de um espécime para a divisão de armas biológicas, para seu benefício pessoal. Apesar de aliados ao capital, os militares lutam corajosamente na defesa dos humanos e Burke acaba morto por um dos alien, malogrando assim os planos da Companhia. O filme acaba por, otimisticamente, assumir um futuro em que a camaradagem e a família se estruturam como os polos positivos do capital, capazes de gerar movimentos de resistência organizada contra o domínio dos seus interesses.

No terceiro filme a ação decorre numa instituição prisional reduzida ao mínimo de habitantes. O tempo continua a ser o futuro, mas David Fincher oferece ao espetador uma retrovisão, uma possibilidade de futuro fundada num passado. Pouco é dado a conhecer sobre o planeta, além da hostilidade dos elementos e do aparente abandono, mas as instalações prisionais assemelham-se a um edifício do século XIX, velho, sujo e labiríntico. Os seus ocupantes, vinte e cinco criminosos violentos, parecem também saídos de um passado distante, de um tempo pré-moderno, anterior à racionalidade, à ciência e à tecnologia. Fincher não propõe encontrar no passado a base para pensar um futuro melhor. O universo de Fiorina não é utópico. A ausência de tecnologia não os torna mais fortes ou capazes na luta contra o alien, e a fé, embora promotora de laços e rituais, não se revela mais eficaz do que a racionalidade e disciplina dos marines de Aliens - O Reencontro Final. A Companhia continua a ser o inimigo, mantendo o interesse na espécie alienígena enquanto fonte de poder, lucro e eventual vantagem militar, e o desprezo pela vida humana. Daí que a visão proposta pelo Alien - A Desforra continue a ser distópica, sugerindo o sacrifício individual redentor como estratégia de resistência.

No quarto filme é explícita a aliança entre os interesses económicos, o aparelho militar e a ciência, unidos na ambição e na indiferença pela vida 
e valores humanos. A proposta de Jeunet é igualmente distópica: nem a Terra, nem a nave em que decorre a ação, nem mesmo as colónias parecem ser locais aprazíveis, melhores do que o mundo zero. No entanto, as estratégias de resistência vão além do sacrifício pessoal, sem que com isso se possa considerar que o filme propõe uma distopia crítica. São os fora da lei, os híbridos, os subprodutos, os impuros, os que resistem à institucionalização, quem sobrevive à crueldade dos aliens e da Companhia, adequando-se ao discurso pós-moderno de fluidez, fragmentação e plasticidade identitárias e à hibridação e ciborguização enquanto estratégias de conciliação das dicotomias modernas. O que fica em aberto no final da tetralogia é a ida de Ripley para a terra. Mas não deixa de haver ironia no facto de o alien finalmente chegar ao planeta no ADN da mulher que lutou durante quatro filmes para o evitar.

Muitos são os autores que defendem os objetivos pedagógicos da tetralogia, em relação aos perigos da ciência, da tecnologia, do capitalismo expansionista ou da necessidade de afirmação do feminino. No entanto, Greenberg (id.) não aceita estes argumentos. Considera que estes filmes não podem ser legitimamente considerados críticos em relação ao capitalismo na medida em que as suas formas de produção e a sua ideologia são, elas próprias, ditadas por parâmetros corporativos e, acrescente-se, motivadas pelo lucro. Podem apreender o egoísmo do capitalismo tardio e apontar para as causas que conduziram a humanidade à ambiguidade moral, mas só podem recomendar soluções escapistas individuais e não formas organizadas de luta com potencial pedagógico.

De acordo com esta perspetiva, as visões propostas pelos quatro realizadores não podem classificar-se como distopias críticas, mas isso não lhe retira o potencial reflexivo. Enquanto forma de entretenimento de massas e enquanto género de sucesso, a ficção científica tem o poder de chegar a audiências que, de outro modo, dificilmente seriam mobilizadas para uma análise crítica do presente e para uma reinvenção de futuro, em que são articuladas questões relativas aos limites e fronteiras de classe, género, identidade, alteridade, tecnologia, ciência, racionalidade, afetividade, maternidade, paternidade, criação, normalidade, aparência e essência. Os filmes 
são tematicamente ricos e, ainda que sejam fruto do capitalismo que criticam e não possam apresentar vias de resistência coletiva sem pôr em risco a sua própria sobrevivência enquanto forma de entretenimento, não deixam de plantar no espírito do espetador a semente que o poderá conduzir à reflexão pessoal, ao debate e à ação que permite construir o futuro.

O quinto filme está em produção, e o presente, tal como as narrativas, continua a obrigar a uma constante reinvenção de outros tempos, futuros ou passados, e de outros espaços, terrestres ou alienígenas, que garantam o distanciamento físico e temporal que permite a reflexão e a reinvenção constante daquilo que é e do que representa ser humano. 


\section{CONCLUSÃo}

Can I dream?

Newt

A análise dos quatro filmes da saga Alien permite comprovar a importância das ansiedades do mundo real na imaginação do futuro. Cada uma das narrativas reflete o mundo em que foi construída, projetando no futuro as ansiedades reais do presente histórico.

Apesar do investimento na construção do monstro, o filme de 1979 não se centra na alteridade, mas na tecnologia e no modo como esta pode ameaçar os valores e integridade humanas e estabelecer-se como fator de sustentação de uma visão distópica. O Alien - O Reencontro Final, lançado em 1986, enquadra-se já no ciclo seguinte, em que é reavaliado e redimido o potencial da tecnologia, encarando-a de forma otimista. A alteridade, por seu lado, é explorada enquanto entidade biológica e inimigo organizado, permitindo a construção de uma narrativa militar num mundo profundamente militarizado.

No terceiro filme, tempo e espaço tornam-se categorias dominantes, criando uma retrovisão, um futuro que é uma projeção do passado e em que a ciência e a tecnologia não existem, adquirindo um tom místico em que dominam elementos de uma racionalidade pré-moderna.

Em Alien - O Regresso é a alteridade, nas múltiplas possibilidades de hibridação, que constitui o centro da narrativa, e a ciência, mais do que a tecnologia, assume protagonismo enquanto dispositivo que permite a replicação e a fusão entre humano e não humano, ignorando os perigos implicados. 
O alien proposto pela tetralogia é um ser visualmente interessante, morfologicamente rico, biologicamente complexo, socialmente estruturado e psicologicamente diferente do humano, sem fragilidades físicas ou emocionais, estabelecendo-se como radicalmente outro, como o absolutamente estranho com o qual não há comunicação nem entendimento e que, por isso, se institui como inimigo.

No filme de 1997 a oposição entre humano e não humano deixa de ser clara, ocorrendo uma monstrização do humano e uma humanização do monstro. No entanto, apesar da hibridação alienígena/humano, não se dá a reconciliação entre as duas categorias, uma vez que só a entidade de matriz humana pode sobreviver.

A hibridação apenas não é aceite na combinação alien/humano, dado que todos os outros sobreviventes da nave são seres de fronteira: com a animalidade no caso de Johner e com a tecnologia nos casos da androide Call e do ciborgue Vriess, confirmando que é na dissolução de antinomias que se constrói o modelo de identidade que melhor se adequa à realidade pós-moderna, permitindo também a afirmação da resistência, adaptabilidade e superioridade do feminino.

Entre o primeiro e o último filme há uma mudança radical no modo como é encarada a tecnologia. Em Alien - O Oitavo Passageiro o androide Ash e o computador Mother são o espelho tecnológico do alien, entidades que se opõem ao humano de modo irreconciliável. Nos filmes seguintes o computador deixa de ser protagonista, e mesmo Father, computador do último filme, é pouco mais do que uma referência intertextual sem existência autónoma ou malevolência intrínseca. Quanto aos androides, ignorando o terceiro filme, há um apuramento moral ao longo da série, de Ash, o frio oficial de ciência ao serviço da Companhia, passando por Bishop, o ser mecânico fiel às leis da robótica, até Call, a androide de segunda geração, demasiado humana para ser apenas humana, sublinhando a ideia de que poderá ser necessário humanizar a humanidade e que a tecnologia poderá instituir-se como o lugar onde a igualdade e a diferença, a identidade e a alteridade se podem conciliar.

Qualquer dos quatro filmes propõe visões distópicas, traduzindo o ceticismo da ficção científica recente em relação a tempos e lugares mais felizes. O capitalismo das grandes empresas e conglomerados é o principal 
agente de desumanização, aliando-se, ao longo das narrativas, à tecnologia, ao aparelho militar e à ciência. No entanto, são propostos movimentos de resistência, mais ou menos organizada, contra os dois inimigos: o alien e a Companhia, podendo por isso considerar-se que os filmes refletem algum otimismo antropológico e esperança em relação ao futuro. A questão da virtualização da realidade, tema da ficção científica recente, não se coloca diretamente em nenhum dos filmes, embora a clonagem obrigue a uma reflexão sobre o estatuto de Ripley, clone número oito, enquanto original ou cópia. A questão da identidade acaba por ser resolvida pela existência de memórias correspondentes aos factos vividos por Ellen Ripley, o que lhe confere continuidade existencial, lhe garante individualidade e permite a identificação com a personagem dos filmes anteriores.

Legatária da racionalidade científica moderna, a ficção científica acompanha as conquistas do saber que mapeiam o mundo e nomeiam a estranheza, partilhando os seus desenvolvimentos e traduzindo as ansiedades, controvérsias e dilemas que despertam. Fá-lo oferecendo uma forma alternativa de narrar o presente, assente numa racionalidade mais ampla, que utiliza a imaginação enquanto capacidade de projetar e de reorganizar o existente de modo crítico e epistemologicamente válido, mas que mantém o respeito pelas suas evidências e a obediência às suas leis.

Para a compreensão das narrativas de ficção científica, especificamente no seu modo cinematográfico, é exigido do recetor uma construção ativa do significado, que consiste num movimento simultâneo de interpretação do futuro à luz do presente e do presente à luz do futuro que obriga, mesmo sem esforço, a uma reflexão epistemológica e ontológica sobre os limites do mundo e do humano.

Imaginar o estranho, o diferente, o outro, trate-se de tempo, espaço ou entidades biológicas e mecânicas, é a proposta dos filmes da saga Alien, construindo narrativas ficcionais onde se articulam as ansiedades de um presente que pode existir em qualquer tempo. Daí a sua atualidade quatro décadas depois e a vontade de continuar a saga para além ou aquém dos personagens e territórios mapeados. Porque, mesmo sabendo que os monstros são reais e às vezes habitam dentro de nós, queremos continuar a sonhar. 
(Página deixada propositadamente em branco) 


\section{B I B L I O GRA F I A}

BACCOLINI, Raffaella e MOYLAN, Tom (2003). Dark Horizons: Science Fiction and the Dystopian Imagination. New York and London: Routledge.

BARR, Marleen (1992). Feminist Fabulation: Space/Postmodern Fiction. Iwoa: University of Iwoa Press.

BIZONY, Piers (1994). 2001: Filming the Future. London: Aurum Press Limited.

BROOKER, Will and Jermyn, Deborah eds. (2003); The Audience Studies Reader, London and NY: Routledge.

BUKATMAN, Scott (1993). Terminal Identity: The Virtual Subject in Postmodern Science Fiction. Durham and London: Duke University Press.

BURAWOY, Michael et al. (1991). Ethnography Unbound. Power and Resistance in the Modern Metropolis. Berkeley: University of Califórnia Press.

CARTMELL, Deborah et al., eds. (1999). Alien Identities: Exploring Differences in Film and Fiction. London: Pluto Press.

CLUTE, John e NICHOLLS, Peter (1993). The Enciclopedia of Science Fiction. New York: Orbit.

ELSAESSER, Thomas e BUCKLAND, Warren (2002). Studying Contemporary American Film: A Guide to Movie Analysis. New york: Oxford University Press.

FEATHERSTONE, Mike (1995). Undoing Culture - Globalization, Postmodernism and Identity. London: Sage Publications.

FEATHERSTONE, Mike e BURROWs, Roger, eds. (1995). Cyberspace, Cyberbodies, Cyberpunk: Cultures of Technological Embodiment. London: Sage Publications.

FEEDMAN, Carl (2000). Critical Theory and Science Fiction. Hanover: Wesleyan University Press.

FREEDMAN, Carl (2000). Critical Theory and Science Fiction. Hanover and London: University Press of New England.

GALLARDO, Ximena e SMITH, C. Jason (2004). Alien Woman: The Making of Lt. Ellen Ripley. New York, London: Continuum.

GRANT, Barry Keith (2003). Film Genre Reader III. Austin: University of Texas Press.

HALL, Stuart e GAY, Paul du, eds. (1996). Questions of Cultural Identity. London: Sage Publications.

HALL, Stuart (1997). Identidades Culturais na Pós-Modernidade. Rio de Janeiro: DP\&A Editora.

HARAWAY, Donna (1989). Primate Visions: Gender, Race and Nature in the World of Modern Science. New York: Routledge.

HARAWAY, Donna (1991). Simians, Cyborgs, and Women. London: Free Association Press. 
HARDY, Phil ed. (1995). The Aurum Film Encyclopedia: Science Fiction. London: Aurum Press.

HEATH, Stephen (1981). Questions of Cinema: Theories of Representation and Difference. Bloomington: Indiana University Press.

HENDERSON, C. J. (2001). The Encyclopedia of Science Fiction Movies from 1987 to the Present. New York: Checkmark Books.

JAMES, Edward e MENDLESOHN, Farah, eds. (2003). The Cambridge Companion to Science Fiction. Cambridge: Cambridge University Press.

JAMES, Edward (1994). Science Fiction in the Twentieth Century. Oxford/New York: Oxford University Press.

JAMESON, Fredric (1995). The Geopolitical Aesthetic: Cinema and Space in the World System. Bloomington, Indiana: Indiana University Press.

JAMESON, Fredric (2005). Archaeologies of the Future: The Desire Called Utopia and Other Science Fictions. New York: Verso.

KAVENEY, Roz (2005). From Alien to the Matrix: Reading Science Fiction Film. London, New York: I. B. Tauris.

KUHN, Annette, ed. (1990). Alien Zone: Cultural Theory and Contemporary Science Fiction Cinema. London, New York: Verso.

KUHN, Annette ed. (1999). Alien Zone II: The Spaces of Science Fiction. London, New York: Verso.

LENAFU, Sarah (1989). Feminism and Science Fiction, Bloomington, Indianopolis: Indiana University Press.

MALMGREN, Carl D. (1991). Wolds Apart - Narratology of Science Fiction. Bloomington e Indianapolis: Indiana University Press.

MAST, Gerard; COHEN, M. e BRAUDY, Leo, eds. (1992). Film Theory and Criticism: Introductory Readings, New York: Oxford University Press.

MCCAFERY, Larry ed. (1994). Storming the Reality Studio: A Casebook of Cyberpunk and Postmodern Science Fiction. Durham: Duke University Press.

METZ, Christian (1974). Film Language: A Semiotics of the Cinema. New York: Oxford University Press.

METZ, Christian (1982). Psychoanalysis and Cinema: The Imaginary Signifier. London: Macmillan.

MITRY, Jean (1990). The Aesthetics of the Cinema. Bloomington: Indiana University Press.

NEUMAN, Dietrich (1999). Film Arquitecture - From Metropolis to Blade Runner. Munique, London: Prestel.

PARRINDER, Patrick, ed. (2000). Learning from other Worlds: Estrangement, Cognition and the Politics of Science Fiction and Utopia. Liverpool: Liverpool University Press.

PARRINDER, Patrick, ed. (1979). Science Fiction: A Critical Guide. London, New york: Longman.

PENLEY, Constance et al., eds. (1993). Close Encounters - Film, Feminism, and Science Fiction. Minneapolis, London: University of Minnesota Press.

PERKOWITZ, Sidney (2007). Hollywood Science - Movies, Science and the End of the World. New York: Columbia University Press.

REDMOND, Sean, ed. (2004). Liquid Metal: The Science Fiction Film Reader. London, New York: Wallflower Press.

ROBERTS, Adam (2000). Science Fiction. London, New York: Routledge.

ROBERTS, Robin (1993). A New Species: Gender and Science in Science Fiction. Urbana, Chicago: University of Illinois Press. 
ROSE, Mark (1981). Alien Encounters: Anatomy of Science Fiction. Cambridge, Massachusetts: Harvard University Press.

SCHELDE, Per (1993). Androids, Humanoids, and Other Science Fiction Monsters: Science and Soul in Science Fiction Movies. New York, London: New York University Press.

SCHOLES, Robert (1975). Structural Fabulation: An Essay on Fiction of the Future; London: University of Notre Dame Press.

SEARLES, B. e LAST, M. (1979). A reader's guide to science fiction. New York: Facts on File.

SOBCHACK, Vivian Carol (1980). The Limits of Infinity: The American Science Fiction Film. New Jersey: Barnes and Co.

SUVIN, Darko (1979). Metamorphoses of Science Fiction: On the poetics and History of a Literary Genre. New Haven, London: Yale University Press.

TElOTTE, J. P. (1995). Replications - A Robotic History of the Science Fiction Film. Urbana / Chicago: University of Illinois Press.

TElotTe, J. P. (2001). Science Fiction Film. Cambridge: Cambridge University Press.

THOMSON, David (1998). The Alien Quartet. London: Bloomsbury Publishing.

TURKLE, Sherry (1995). Life on the Screen. Cambridge: MIT Press.

WELDES, Jutta, ed. (2003). To Seek Out New Worlds: Exploring Links between Science Fiction and World Politics. New York: Palgrave Macmillan.

WOLFE, Gary K. (1986). Critical Terms for Science Fiction and Fantasy: A Glossary and Guide to Scholarship. Connecticut: Greenwood Pres 
(Página deixada propositadamente em branco) 


\section{FILMOGRAFIA}

2001: A Space Odyssey (2001: Odisseia no Espaço). 1968. Stanley Kubrick. Warner Studios. Alien [Alien: O Oitavo Passageiro]. 1979. James Cameron. 20th Century Fox.

Alien3 [Alien: A Desforra]. 1992. David Fincher. 20th Century Fox.

Alien Ressurrection [Alien: O Regresso]. 1997. Jean-Pierre Jeunet. 20th Century Fox.

Aliens [Aliens: O Reencontro Final]. 1986. James Cameron. 20th Century Fox.

Alien Quadrilogy. 2003. Special Edition. Fox Home Entertainment.

Alien vs Predador. 2004. Paul Anderson. 20th Centutry Fox.

Alien vs Predador: Requiem. 2007. Colin Strause e Greg Strause. 20th Centutry Fox.

Avatar. 2009. James Cameron. 20th Century Fox.

Blade Runner [Blade Runner: Perigo Iminente]. 1982. Ridley Scott. Columbia Tristar Home.

Cité des Enfants Perdus, La [A Cidade das Crianças Perdidas]. 1995. Marc Caro e Jean-Pierre Jeunet. Columbia/Tristar Pictures Television.

Death Becomes Her [A Morte Fica-lhes Tão Bem]. 1992. Robert Zemeckis. Universal Pictures.

Delicatessen. 1991. Marc Caro e Jean-Pierre Jeunet. Paramount Studios.

Dark Star.1974. John Carpenter. VCI Home Videos.

Jurassic Park [Parque Jurássico]. 1993. Steven Spielberg. Universal Pictures.

Navigator, The: A Medieval Odyssey [O Navegador: Uma Odisseia Medieval]. 1988. Vincent Ward. Hen's Tooth Video.

Panic Room [Sala de Pânico]. 2002. David Fincher. Columbia Pictures.

Predator [O Predador]. 1987. John McTiernan. 20th Century Fox.

Rambo: First Blood [Rambo]. 1985. George P. Cosmatos. Artisan Entertainment.

Terminator, The [O Exterminador Implacável]. 1984. James Cameron. Artisan Entertainment.

Thing, The [Veio de Outro Mundo]. 1982. John Carpenter. Universal Studios. 
Série Investigação

Imprensa da Universidade de Coimbra

Coimbra University Press

2012

- $\mathbf{U}$

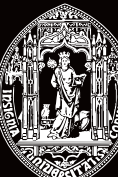

C •

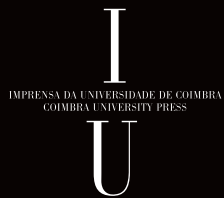

